\title{
Atmospheric Composite Sounding Analysis as a Forecasting Tool for Ozone Accumulation in a Semiarid Metropolitan Area during the North America Monsoon: Phoenix, Arizona
}

\author{
JONNY WILLIAM MALLOY \\ School of Geographical Sciences and Urban Planning, Arizona State University, Tempe, and Air Quality Division, \\ Arizona Department of Environmental Quality, Phoenix, Arizona
}

RANDALl S. CERVENY

School of Geographical Sciences and Urban Planning, Arizona State University, Tempe, Arizona

(Manuscript received 18 December 2018, in final form 5 April 2019)

\begin{abstract}
Phoenix, Arizona, observes a high summertime frequency for daily maximum 8-h ozone averages (DMO8) exceeding 70 parts per billion, resulting in nonattainment status by the U.S. Environmental Protection Agency. This study discusses the use of composite atmospheric sounding analysis (constructing average sounding conditions for specific recurring events) to forecast different air quality index daily ozone classifications, including "good," "moderate," and collectively categories exceeding the 2015 ozone standard. Composite sounding analysis, using the Phoenix 1200 UTC (0500 LST) rawinsonde data (2006-17), identifies "pollutant dispersion windows" for ozone accumulation or dispersal for Phoenix during the North American monsoon (July and August period). A favorable ozone exceedance atmosphere is associated with a "Four Corners high" synoptic pattern bringing relatively light winds at and below $700 \mathrm{hPa}\left(\leq 4.5 \mathrm{~ms}^{-1}\right)$ and higher easterly winds above $\left(\leq 12.3 \mathrm{~ms}^{-1}\right)$. Healthy ozone days ( $\operatorname{good}$ category) are common when Pacific low pressure troughing over the western United States creates deep and faster westerly flow above the surface reaching speeds of $6.7(19.5) \mathrm{m} \mathrm{s}^{-1}$ by 700 (200) $\mathrm{hPa}$. Surprisingly, large standard deviations over $10^{\circ} \mathrm{C}$ for dewpoint temperature at midlevels $(500-400 \mathrm{hPa})$ were determined for all three daily ozone classification ranges used in this study. Additionally, modest temperature deviations and mean differences are noted at significant pressure levels. Consequently, wind speed and direction are better indicators when forecasting ozone accumulation potential. These results are pertinent to air quality meteorologists responsible for disseminating ozone forecasts for heavily urbanized areas of the U.S. Southwest.
\end{abstract}

\section{Introduction}

Tropospheric ozone poses a risk to both human health (Gold et al. 1996; Owens et al. 2017) and vegetation (Mills et al. 2016). The formation of ozone is derived through complex photochemical chemical reactions primarily between sunlight, oxygen, oxides of nitrogen, and volatile organic compounds (Quincey et al. 2007; Wayne 1987). Phoenix, Arizona, has been shown to be susceptible to recurring ozone levels reaching unhealthful levels based on U.S. Environmental Protection Agency (EPA) pollutant standards (Malloy 2018). Consequently, the

\footnotetext{
Corresponding author: Jonny William Malloy, Jonny.Malloy@ asu.edu
}

Phoenix mean statistical area (MSA) represents a designated nonattainment area for ozone, specifically concerning the daily maximum 8 -h average (DMO8) (Fig. 1a). The MSA populace has nearly five million residents as of 2017 (U.S. Census Bureau 2018) making it the eleventh most populated metropolitan area in the United States. This represents a significant population at risk for health effects due excessive ozone concentration exposure.

The Phoenix Nonattainment Area (termed PNA in this study) is spatially large, encompassing an area of nearly $13000 \mathrm{~km}^{2}$. The PNA is best described as a mixed land use including urban, suburban, and rural zones. The most urbanized area of the PNA is the central business district of Phoenix in south-central portions of the PNA. 


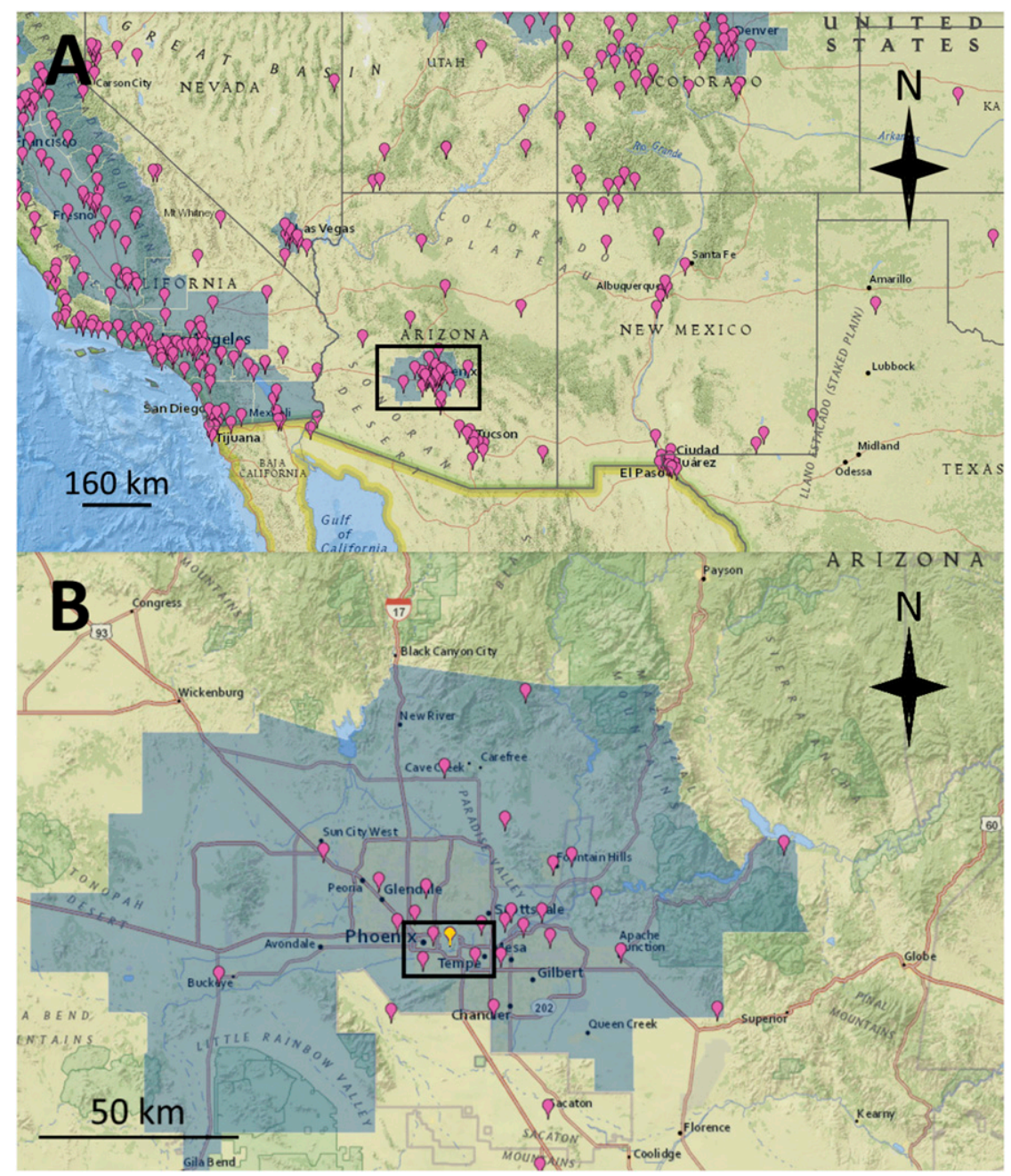

FIG. 1. (a) U.S. Southwest study area. The large black box contains the Phoenix mean statistical area and ozone nonattainment area (gray shading). Pink balloon icons represent active ozone monitoring stations in the region, and the yellow balloon icon represents the Phoenix sounding location. (b) Zoom in of ozone nonattainment area and local topography of Phoenix. The small black box indicates the Phoenix sounding launch location $\left(33.45^{\circ} \mathrm{N}, 111.95^{\circ} \mathrm{W}\right)$ and surface weather observations at Phoenix Sky Harbor International Airport $\left(33.42^{\circ} \mathrm{N}\right.$, $112.00^{\circ} \mathrm{W}$ ). Map details provided by U.S. EPA's AirData App website (U.S. EPA 2018b).

The current ozone monitoring network includes 26 monitoring sites that are maintained by state, local, and tribal air regulatory agencies (Fig. 1b).

Ozone pollutant dispersion patterns over the PNA are heavily dictated by the existence of a prominent topographically induced mountain-valley circulation (Malloy 2018). As noted in Fig. 1, the north and east boundaries of the PNA represent a transition from a lower valley toward desert foothills and significant terrain in excess of $1500 \mathrm{~m}$. The close proximity of nearby higher topography versus the lower elevations of downtown Phoenix (i.e., approximately 380-m elevation) creates a recurring mountain-valley circulation that has been found to be an important factor affecting local diurnal trends in pollution levels (e.g., Ellis et al. 1999; Fast et al. 2000; Lee and Fernando 2013).

On a seasonal basis, the PNA has a high propensity to record elevated surface ozone concentrations during the summer months. During that time of year, the position of the PNA in the northern Sonoran Desert also makes the area subject to influences by the summer North American monsoon (NAM). The NAM is a large-scale atmospheric circulation phenomenon affecting primarily the U.S. Southwest and northern Mexico (Adams and Comrie 1997; Douglas et al. 1993). The NAM is characterized by 1 ) atmospheric instability (Diem and Brown 2009; Heinselman and Schultz 2006), 2) intermittent rainfall (Carleton 1986; Mullen et al. 1998), 3) severe 
TABLE 1. U.S. EPA's AQI categorical schema for highest DMO8 AQI category (U.S. EPA 2018a) with specific definitions for categories and subcategories; occurrences in the PNA from 2006 to 2017 (July-August): total available (with radiosonde data) events per category and total number of events per category.

\begin{tabular}{llcrr}
\hline \hline EPA ozone category & \multicolumn{1}{c}{ Subcategory } & EPA definition & No. of available events & No. of total events \\
\hline Good (GD) & & $0-54 \mathrm{ppb}$ & 85 & 85 \\
Moderate (MD) & & $55-70 \mathrm{ppb}$ & 444 & 453 \\
Exceedance (EXD) & & $70 \mathrm{ppb}$ & 203 & 206 \\
& Unhealthy for sensitive groups & $71-85 \mathrm{ppb}$ & 194 & 196 \\
& Unhealthy & $86-105 \mathrm{ppb}$ & 9 (maximum: $96 \mathrm{ppb}$; 17 and 19 Jul 2006). & 10 \\
& Very unhealthy & $106-200 \mathrm{ppb}$ & 0 & 0 \\
& Hazardous & $\geq 201 \mathrm{ppb}$ & 0 & 0 \\
\hline
\end{tabular}

weather hazards (Brazel and Nickling 1986; King and Balling 1994; Maddox et al. 1995), and 4) varying levels of atmospheric dispersion affecting pollutant buildup potential, including ozone accumulation (e.g., Ellis et al. 2000; Malloy 2018; Shi et al. 2012).

A previous study (Malloy 2018) statistically identified a variety of temperature, moisture, and wind-related meteorological parameters between the surface and $300 \mathrm{hPa}$. Variations in those parameters were found to be statistically significant in their association with days when the DMO8 value in the PNA exceeded the 2015 U.S. EPA standard of 70 parts per billion (ppb) during the months of July and August. Although the Malloy (2018) results were useful in identifying specific thresholds for a range of sounding parameters associated with exceeding days, that study did not explicitly address how significant sounding parameters may be working in concert in reference to daily DMO8 variability, or in other words, it failed to identify the common or average sounding associated with ozone exceedances. This is important in an operational forecasting framework in that leveraging single parameters without context to the overall environment may result in biased and inaccurate forecasts.

Therefore, the intention of this study is to use a rawinsonde composite analysis approach for establishing differences in temperature, moisture, and wind characteristics that have preceded ozone exceedance and nonexceedance situations. The study's fundamental goal is to determine the sounding signatures for the planetary boundary layer (PBL), as well as upper levels, for ozone exceedance days (i.e., DMO8 value $\geq 70 \mathrm{ppb}$ ). To do so, data collected includes the morning vertical environment (1200 UTC or 0500 LST) before peak ozone production in the PNA, which typically occurs in the afternoon hours (e.g., Atkinson-Palombo et al. 2006).

The technique of composite analysis is both viable and accepted in the scientific community for identification of vertical atmospheric variables associated with specific meteorological events, dating back to initial tornado forecasting analyses (Fawbush et al. 1951). More recently, for example, Rodriguez et al (2010) investigated mean differences in sounding parameters between thunderstorm and nonthunderstorm days in São Paul, Brazil, while Schrage et al. (2007) employed composite sounding analysis to determine cloudiness potential during the West African monsoon. Other examples of employing the technique include identifying vertical profile characteristics favoring fog versus nonfog days in northeastern Japan (Sugimoto et al. 2013), using sounding data in the Intermountain West region of the United States to link synoptic influence on the persistence of winter season inversions (Gillies et al. 2010a), and identifying atmospheric conditions preceding severe hail reports in northern Arizona during the NAM (Malloy 2011).

Specific to this study, the method of composite sounding analysis is applied to morning environmental conditions, taken over the PNA area during the NAM, to establish differences between observed exceeding versus nonexceeding DMO8 levels (termed EXD and NEXD, respectively). The period under review is for the months of July and August between 2006 and 2017.

\section{Methodology and data}

\section{a. Phoenix rawinsonde}

The NAM officially begins on 15 June and concludes on 30 September. The study period for this research, however, is restricted to the months of July and August for two major reasons. First, although the NAM may develop early in June and linger into the month of September (Adams and Comrie 1997), historical interseasonal variability for an established monsoon pattern has been shown to be higher for what could be considered the transition months for the onset (June) and breakdown (September) (e.g., Ellis et al. 2004). Second, Phoenix rawinsonde data (1200 and 0000 UTC) are made intermittently through a collaborative effort between the local power-utility company Salt River Project and the National Weather Service Office Phoenix. 
Location of launches have been consistent from year to year within the PNA (see Fig. 1b), yet focus for rawinsonde releases are almost exclusively reserved for the NAM with greatest record availability during the months of July and August. Inclusion of the transition months having relatively limited sample sizes are likely to bias composite type analyses and comparisons.

Furthermore, for this study, rawinsonde data were limited to 1200 UTC (0500 LST) since the aim of the study is establishing common NAM morning vertical profiles before DMO8 exceedances would typically occur in the PNA (e.g., Ellis et al. 1999) for potential use in forecasting unhealthy ozone days. There were no restrictions given on exporting the sounding parameters of pressure height, temperature, dewpoint, wind speed, and wind direction for any specific pressure levels. Complete Phoenix daily soundings totaled 731 out of a possible $744(98.2 \%)$ and were made available by the NOAA/ESRL Radiosonde Database (NOAA/ESRL Physical Science Division 2018).

\section{b. Phoenix DMO8 values}

DMO8 value selection for the study period was limited to the 26 currently active PNA ozone monitoring sites (as of August 2018) (see Fig. 1b) via EPA's Air Quality System (U.S. EPA 2018b). Ozone is monitored by state, local, and tribal governments adhering to the minimum requirements set forth in 40 CFR Part 58 allowing for a National Ambient Air Quality Standards compliant monitoring network (Arizona Department of Environmental Quality; ADEQ 2018).

A total of 732 days (limited by rawinsonde data availability) had at least one valid PNA DMO8 value. Of those days, 206 days were classified as exceedances and 537 were classified as nonexceedance for the 12 monsoon seasons. However, rawinsonde data gaps allowed only 203 of 206 EXD (98.5\%) and 528 of 538 (98.3\%) NEXD to be evaluated with a corresponding 1200 UTC sounding. Effects of this reduction in data should be negligible due to a vast majority of respective EXD and NEXD days still being included for review.

\section{c. Daily ozone classification}

The 1200 UTC rawinsonde measurements were aggregated into mean values to establish the morning temperature, moisture, and wind variability for exceedance and nonexceedance days. Furthermore, the NEXD day group is subdivided based on the following U.S. EPA's air quality index (AQI) categorical schema (U.S. EPA 2018a): "good" (0-54 ppb) and "moderate" (55-70 ppb). According to the U.S. EPA, the moderate AQI range "marks the level above which EPA begins cautioning at-risk groups" (U.S. EPA 2018a). Therefore, days with this
TABLE 2. Phoenix, AZ, 1200 UTC composited sounding mean and standard deviations for temperature $\left({ }^{\circ} \mathrm{C}\right)$, dewpoint $\left({ }^{\circ} \mathrm{C}\right)$, and wind speed $\left(\mathrm{m} \mathrm{s}^{-1}\right)$ at significant pressure levels $(\mathrm{hPa})$ associated with ozone exceedance days.

\begin{tabular}{|c|c|c|c|c|c|c|}
\hline \multirow[b]{2}{*}{ Pressure $(\mathrm{hPa})$} & \multicolumn{2}{|c|}{$\begin{array}{c}\text { Temperature } \\
\left({ }^{\circ} \mathrm{C}\right)\end{array}$} & \multicolumn{2}{|c|}{ Dewpoint $\left({ }^{\circ} \mathrm{C}\right)$} & \multicolumn{2}{|c|}{$\begin{array}{l}\text { Wind speed } \\
\left(\mathrm{m} \mathrm{s}^{-1}\right)\end{array}$} \\
\hline & Mean & Std dev & Mean & Std dev & Mean & Std dev \\
\hline 100 & -71.1 & 2.3 & -85.1 & 2.5 & 6.8 & 3.2 \\
\hline 150 & -64.6 & 1.9 & -78.4 & 4.1 & 11.1 & 6.1 \\
\hline 200 & -52.9 & 1.6 & -67.7 & 6.5 & 12.3 & 6.3 \\
\hline 250 & -41.6 & 1.3 & -56.4 & 8.5 & 10.2 & 5.6 \\
\hline 300 & -31.9 & 1.5 & -46.6 & 10.4 & 8.6 & 4.6 \\
\hline 400 & -16.9 & 1.4 & -31.2 & 11.7 & 6.9 & 3.6 \\
\hline 500 & -6.5 & 1.2 & -15.6 & 10.1 & 6.5 & 3.5 \\
\hline 700 & 12.7 & 1.8 & 3.3 & 5 & 4.5 & 2.5 \\
\hline 850 & 25.1 & 2.6 & 9.7 & 4.5 & 4.3 & 2.7 \\
\hline 925 & 29.4 & 3 & 12.8 & 4.8 & 4.5 & 2.9 \\
\hline 966 (surface) & 29.3 & 2.3 & 15.7 & 4.1 & 2.7 & 1.5 \\
\hline
\end{tabular}

range should be considered for evaluation independent of the good AQI category. No subdivision was given to the EXD group, which for the purpose of this study, encompassed all AQI categories representing DMO8 values over the 70-ppb U.S. EPA exceedance standard. Those AQI categories and ppb ranges are as follows: "unhealthy for sensitive groups" (71-85 ppb), "unhealthy" (86-105), "very unhealthy" (106-200), and "hazardous" ( $\geq 201 \mathrm{ppb}$ ).

Applying the 2015 U.S. EPA standard retroactively to the study period of 2006-17, the highest DMO8 AQI category reached at Phoenix would have been unhealthy with a measurement of $96 \mathrm{ppb}$ occurring twice (17 and 19 July, 2006). Such high concentrations were rare considering the large sample size for EXD versus only ten occurrences over the study period. The resultant distribution of good (GD), moderate (MD), and EXD days for PNA are 203, 444, and 85, respectively. A total of nine MD days and one GD day were not included in the evaluation due to rawinsonde unavailability. A summary of study day classification relative to the U.S. EPA's AQI categories is provided in Table 1.

\section{d. Composite analyses}

Atmospheric sounding composites were created and compared for the three daily ozone classifications after using the merging capability of the Universal Rawindsonde Observation software program. The program's merge option retains all data and interpolates data for standard significant pressure levels only if missing values are present.

To add context for the soundings with associated larger-scale NAM patterns, mean daily $500-\mathrm{hPa}$ geopotential height and 700-hPa vector wind synoptic plots are constructed for each of the three DMO8 

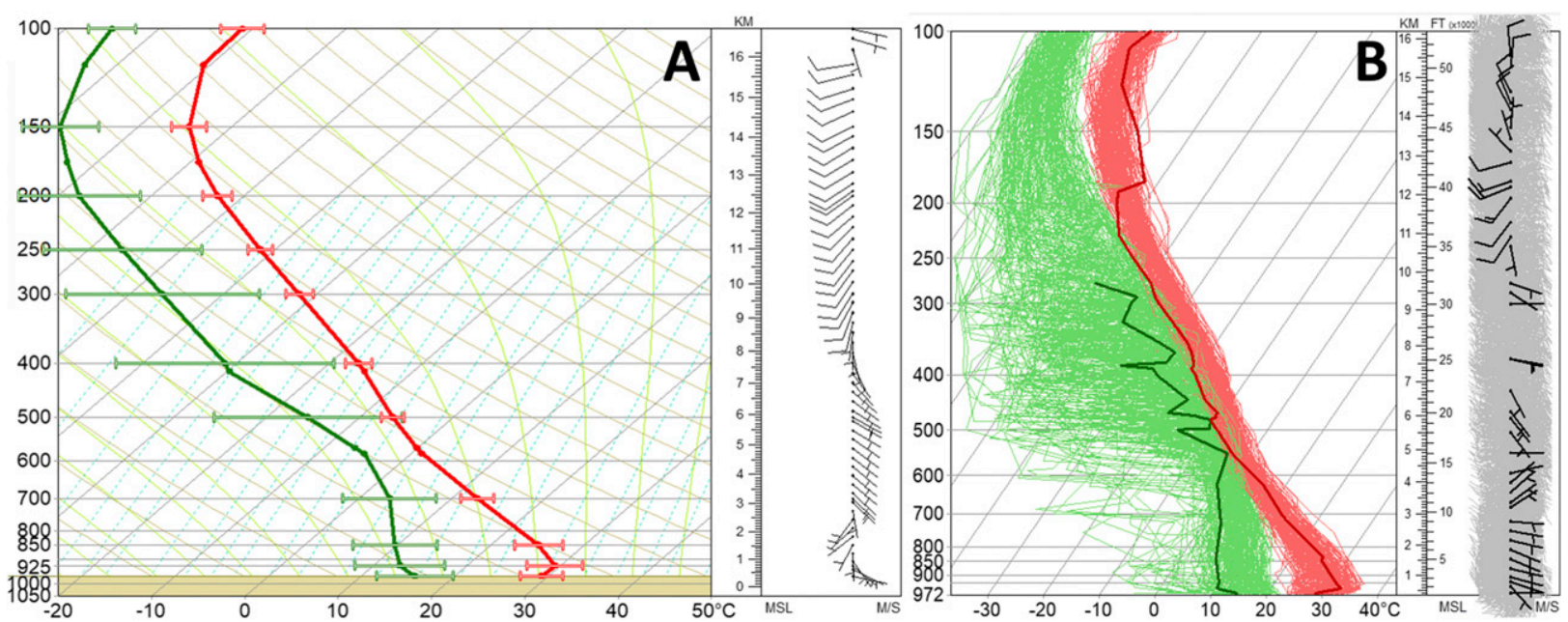

FIG. 2. (a) Mean 1200 UTC composite sounding for Phoenix ozone exceedance days (203). Standard deviation error bars at significant pressure levels $(\mathrm{hPa})$ are plotted for both the dewpoint $\left({ }^{\circ} \mathrm{C}\right.$; green $)$ and temperature $\left({ }^{\circ} \mathrm{C}\right.$; red) mean profiles. Mean atmospheric wind speed $\left(\mathrm{m} \mathrm{s}^{-1}\right)$ and directions are shown on the right. (b) Spaghetti plot of composited days with bold dewpoint, temperature, and wind corresponding to the sounding with greatest DMO8 concentration observed (19 Jul 2006; 96 ppb).

groupings via the widely utilized North American Regional Reanalysis (NARR) dataset intended for research purposes (Mesinger et al. 2006). The 500-hPa height pattern is often relied upon to track the strength and position of the NAM circulation (Adams and Comrie 1997), while the 700-hPa level represents the potential upper extension of the planetary boundary layer (PBL) in the desert areas of the U.S. Southwest during the summer months (Lee and Fernando 2013).

\section{Results and discussion}

\section{a. Phoenix ozone exceedances}

A wide variability in morning midlevel moisture and upper-level wind speeds exists preceding observed DMO8 exceedances in the Phoenix Nonattainment Area (Table 2). Specifically, standard deviations for dewpoint temperatures were $11.7^{\circ} \mathrm{C}$ at $400 \mathrm{hPa}$ and were no less than $4.1^{\circ} \mathrm{C}$ within the PBL. Wind speed standard deviations were less and ranged between a minimum of $1.5 \mathrm{~m} \mathrm{~s}^{-1}$ at the surface to near $6.3 \mathrm{~m} \mathrm{~s}^{-1}$ at the $200-\mathrm{hPa}$ pressure level. However, temperatures in the atmospheric column preceding ozone exceedances exhibited much less deviance; ranging only $1.3^{\circ}-2.6^{\circ} \mathrm{C}$ at any significant pressure level height between the surface and $100 \mathrm{hPa}$.

Atmospheric variability during NAM supporting ozone accumulation in the PNA is demonstrated visually by the large standard deviation ranges for dewpoint at the significant pressure levels (Fig. 2a) and the numerous observed profile configurations seen by the "spaghetti plot" for the 203 composited EXD days
(Fig. 2b). The spaghetti plot diagram displays the compilation of vertical temperature, dewpoint, wind speed, and wind direction observed with individual EXD days overlaid on a single plot. In this study, the spaghetti plot is useful for determining the range of atmospheric conditions that have been associated with discrete ozone concentrations. The greatest DMO8 value recorded in the PNA over the study period was $96 \mathrm{ppb}$ achieved on both 17 and 19 July 2006. The 19 July 2006 profile is highlighted in Fig. $2 b$ to showcase an EXD instance. This date was the sixth straight day reaching exceedance values that began on 14 July 2006. The EXD event continued through 26 July 2006, making the entire period a 13-day air quality episode and the longest consecutive EXD day streak in the study period. Fortunately, with regard to health concerns, such long

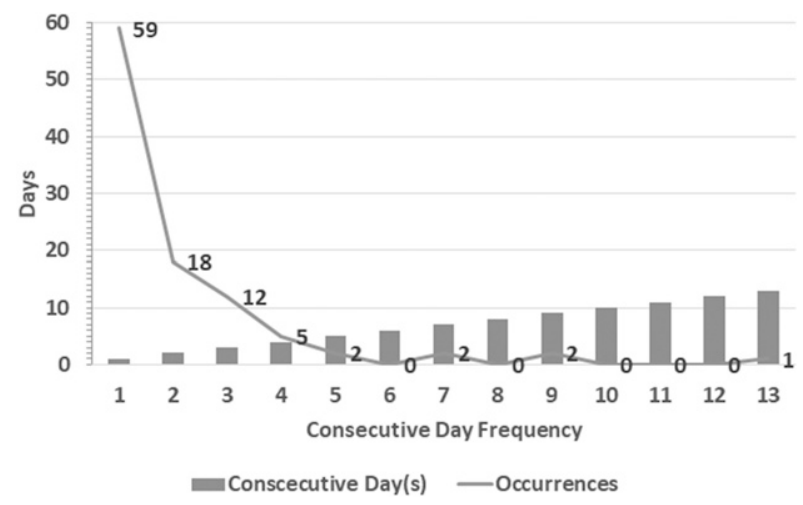

FIG. 3. Ozone exceedance day episode duration frequency for the Phoenix Nonattainment Area during the months of July and August (2006-17). Analysis includes 203 ozone exceedance cases. 


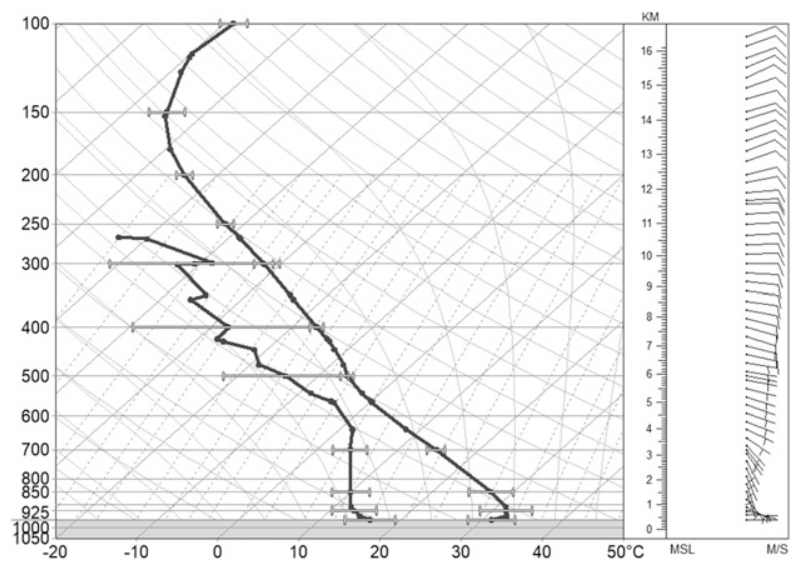

FIG. 4. Mean 1200 UTC composite sounding (dewpoint and temperature in ${ }^{\circ} \mathrm{C}$, wind speed in $\mathrm{m} \mathrm{s}^{-1}$, and pressure height in $\mathrm{hPa}$ ) for the longest Phoenix ozone exceedance air quality episode (1426 Jul 2006) during the months of July and August (2006-17).

duration air quality episodes are rare, with a majority of exceedance events being only one or two days in length (Fig. 3).

Key features of the 19 July 2006 morning sounding profile include the following: 1) a warm and dry inversion near the surface, 2) light easterly to southeasterly flow in the PBL (sub-700 hPa), and 3) cloud cover potential near 500-hPa pressure level based on low dewpoint depression values. Otherwise, light winds throughout the column dominated between the surface and $400 \mathrm{hPa}$ $\left(\leq 5 \mathrm{~m} \mathrm{~s}^{-1}\right)$. However, this particular profile should not be considered the only ozone exceedance environment for the PNA given the differences in soundings found for the collective EXD group, especially when considering the variability in vertical profiles throughout the air quality episode noted previously (Fig. 4).

It is also important to note that both saturated and unsaturated conditions have preceded DMO8 exceedances. The study area's high day-to-day variability in atmospheric moisture readings during the July and August monsoon period is not a surprising finding. Intraseasonality differences for moisture affecting rain and cloud cover has been well documented for the North American monsoon (e.g., Carleton 1986; Heinselman and Schultz 2006). What is more important in this finding is that unhealthful DMO8 values may be independent of ambient moisture readings. For instance, although excessive moisture leading to clouds would interrupt the photochemical process necessary for new ozone formation (Wayne 1987), cloudiness does not preclude higher ozone concentrations already in the region. In the absence of cloud cover, elevated moisture in the PBL may act to limit vertical mixing due to a more homogeneous profile allowing local ozone production to
TABLE 3. Phoenix, AZ, 1200 UTC composited sounding mean and standard deviations for temperature $\left({ }^{\circ} \mathrm{C}\right)$, dewpoint $\left({ }^{\circ} \mathrm{C}\right)$, and wind speed $\left(\mathrm{m} \mathrm{s}^{-1}\right)$ at significant pressure levels $(\mathrm{hPa})$ associated with ozone moderate AQI days.

\begin{tabular}{|c|c|c|c|c|c|c|}
\hline \multirow[b]{2}{*}{ Pressure $(\mathrm{hPa})$} & \multicolumn{2}{|c|}{$\begin{array}{c}\text { Temperature } \\
\left({ }^{\circ} \mathrm{C}\right)\end{array}$} & \multicolumn{2}{|c|}{ Dewpoint $\left({ }^{\circ} \mathrm{C}\right)$} & \multicolumn{2}{|c|}{$\begin{array}{l}\text { Wind speed } \\
\left(\mathrm{m} \mathrm{s}^{-1}\right)\end{array}$} \\
\hline & Mean & Std dev & Mean & Std dev & Mean & Std dev \\
\hline 100 & -70.7 & 2.3 & -85.1 & 2.5 & 6.7 & 3.3 \\
\hline 150 & -64.7 & 1.8 & -78.5 & 4.1 & 13.7 & 6.8 \\
\hline 200 & -52.6 & 1.4 & -67.2 & 7 & 15.8 & 7.8 \\
\hline 250 & -41.4 & 1.6 & -57.3 & 9.3 & 13.2 & 6.9 \\
\hline 300 & -31.8 & 1.7 & -49.5 & 10.5 & 10.6 & 5.9 \\
\hline 400 & -16.8 & 1.6 & -35.7 & 12.1 & 7.6 & 4.2 \\
\hline 500 & -6.4 & 1.4 & -18.8 & 12 & 6.5 & 3.5 \\
\hline 700 & 11.7 & 1.7 & 4 & 4.5 & 5.0 & 2.8 \\
\hline 850 & 24.1 & 2.4 & 9.5 & 5.4 & 4.5 & 2.5 \\
\hline 925 & 28.8 & 2.6 & 12.3 & 5.6 & 4.6 & 2.8 \\
\hline 966 (surface) & 28.8 & 2.1 & 15.1 & 4.5 & 2.7 & 1.8 \\
\hline
\end{tabular}

accumulate. Additionally, ozone is not removed directly by rainfall should adequate moisture and instability exist (e.g., U.S. EPA 2003).

In contrast to a moist environment, an unsaturated profile promotes ultraviolet light to reach the surface and support photochemistry of new ozone formation (Wayne 1987), while increased insolation also encourages deep vertical mixing and fumigation of aged ozone aloft toward the surface. Although, moisture is noted to be quite variable, it is apparent that for the composited EXD group there is an inclination toward a light wind regime (generally under $5 \mathrm{~m} \mathrm{~s}^{-1}$ ) below $500 \mathrm{hPa}$ with veering winds between the surface and $850 \mathrm{hPa}$, then abrupt change to backing winds through $500 \mathrm{hPa}$ (Fig. 2a).

It is unclear at this time what the direct influence of weaker upper-level winds is on surface ozone concentrations; however, the identified easterly flow for higher ozone concentrations has been found to be significant for the Phoenix area (i.e., Malloy 2018). This is due to the regional wind pattern flowing against the local mountain-valley circulation and likely contributing to an ozone rich layer over the city that fumigates toward the surface during periods of deep vertical mixing. Since fumigation (or convectively down-mixing) of aged ozone found in a residual layer aloft can occur after entrainment by daytime extension of the PBL (e.g., Lee and Fernando 2013; Shi et al. 2012), dispersion patterns in the upper PBL are an important consideration for forecasting ground-level ozone.

\section{b. Phoenix ozone moderate AQI days}

Similar to the EXD group there is no single ideal 1200 UTC atmospheric profile indicative of a moderate AQI ozone day given the amount of combinations for 


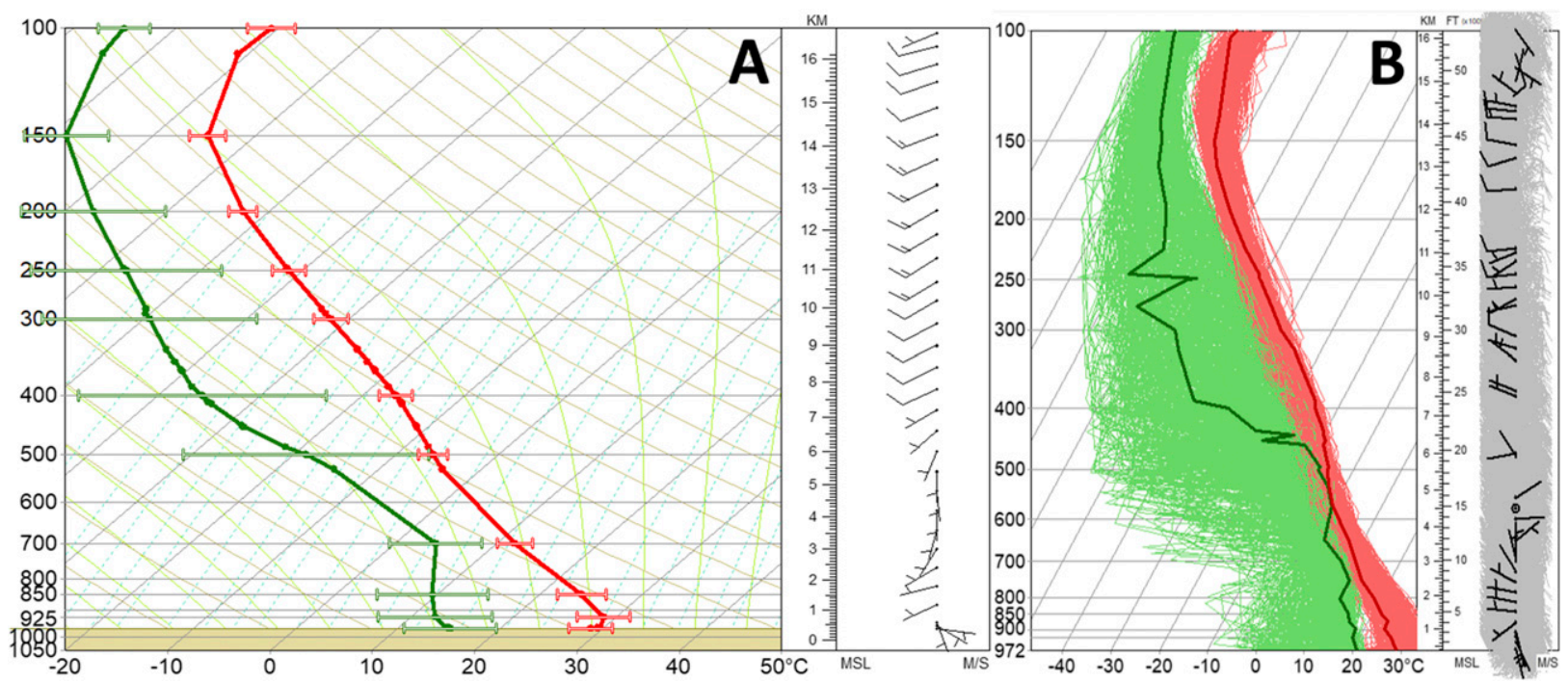

FIG. 5. (a) Mean 1200 UTC composite sounding for Phoenix ozone moderate AQI days (444). Standard deviation bars at significant pressure levels $(\mathrm{hPa})$ are plotted for both the dewpoint $\left({ }^{\circ} \mathrm{C}\right.$; green $)$ and temperature $\left({ }^{\circ} \mathrm{C}\right.$; red) mean profiles. Mean atmospheric wind speed $\left(\mathrm{m} \mathrm{s}^{-1}\right)$ and directions are shown on the right. (b) All composited soundings with the bolded dewpoint, temperature, and wind corresponding to the sounding observed on the date recording a DMO8 concentration in the middle of the moderate AQI categorical range (55-70 ppb) (27 Jul 2017; $63 \mathrm{ppb).}$

temperature, moisture, and wind that existed for the 444 days. Midlevel moisture near $500 \mathrm{hPa}$ and wind speeds aloft near $200 \mathrm{hPa}$ exhibited the greatest variation having large standard deviations up to $12.1^{\circ} \mathrm{C}$ and $7.8 \mathrm{~m} \mathrm{~s}^{-1}$, respectively (Table 3 ). Once again, temperature at all significant levels showed little variability. Throughout the vertical column a temperature deviation of no more than $2.6^{\circ} \mathrm{C}(925 \mathrm{hPa})$ was noted. Overall, the PBL did demonstrate the greatest variability in temperature. In similar fashion to Fig. 2, the composited sounding for the $444 \mathrm{MD}$ days is shown with standard deviation bars (Fig. 5a) along with the ensemble of all MD used in the study (Fig. 5b).

The composited MD versus EXD sounding reveals several noteworthy differences. First, EXD day mornings have slightly warmer PBL readings up to $1^{\circ} \mathrm{C}$ (Figs. 6a and 6b). Second, midlevel moisture is relatively higher considering dewpoint readings on the order of $4.5^{\circ} \mathrm{C}$ warmer between 500 and $400 \mathrm{hPa}$ (Figs. $6 \mathrm{c}$ and $6 \mathrm{~d}$ ). Finally, dispersion patterns in terms of wind speed and direction are distinct. Specifically, weaker upper-level winds (Figs. 7a and 7b) and an easterly versus westerly wind component between the upper PBL (near $700 \mathrm{hPa}$ ) and $400-$ hPa pressure levels (Figs. $7 \mathrm{c}$ and $7 \mathrm{~d}$ ) favor EXD days.

Overall, early morning surface conditions are nearly identical when comparing MD and EXD days with temperatures around $29^{\circ} \mathrm{C}$ and wind speeds near $3 \mathrm{~m} \mathrm{~s}^{-1}$ displaying an easterly component. This reflects a documented persistent diurnal flow due to regional topography
(Ellis et al. 1999). Major distinctions only arise higher in altitude demonstrating that a focus on surface considerations alone is not sufficient to forecast ozone levels.

\section{c. Phoenix ozone good AQI days}

Unfortunately, for the Phoenix Nonattainment Area during the months of July and August, good AQI ozone days are relatively rare with a sample size of only 85 out of 731 study days evaluated $(11.4 \%)$. In relation to both EXD and MD days, large standard deviations for environmental dewpoint and wind speed at the midlevels and upper levels, respectively, are also evident (Table 4).

The composited GD sounding is provided in Fig. 8a with the variability in individual profiles shown by Fig. 8b. The lowest observed DMO8 concentration over the study period was 38 ppb observed on 10 July 2015 and is highlighted in bold in Fig. 8b. When distinguishing between EXD days, GD are cooler in the PBL up to $3^{\circ} \mathrm{C}$ (Figs. 9a and 9b), and similar to the contrast between MD and EXD classifications, are drier in the midlevels with dewpoints around $4^{\circ} \mathrm{C}$ lower (Figs. 9c and $9 \mathrm{~d})$.

The clear difference between GD and the EXD or MD groups is a deep and faster westerly flow (Fig. 10). Under this pattern, it is likely that 1) aged ozone aloft over the PNA would be transported downwind to limit local fumigation potential (e.g., Lee et al. 2003) and that 2) the diurnal ozone plume developing near the surface of the Phoenix urban area undergoes higher dispersion 

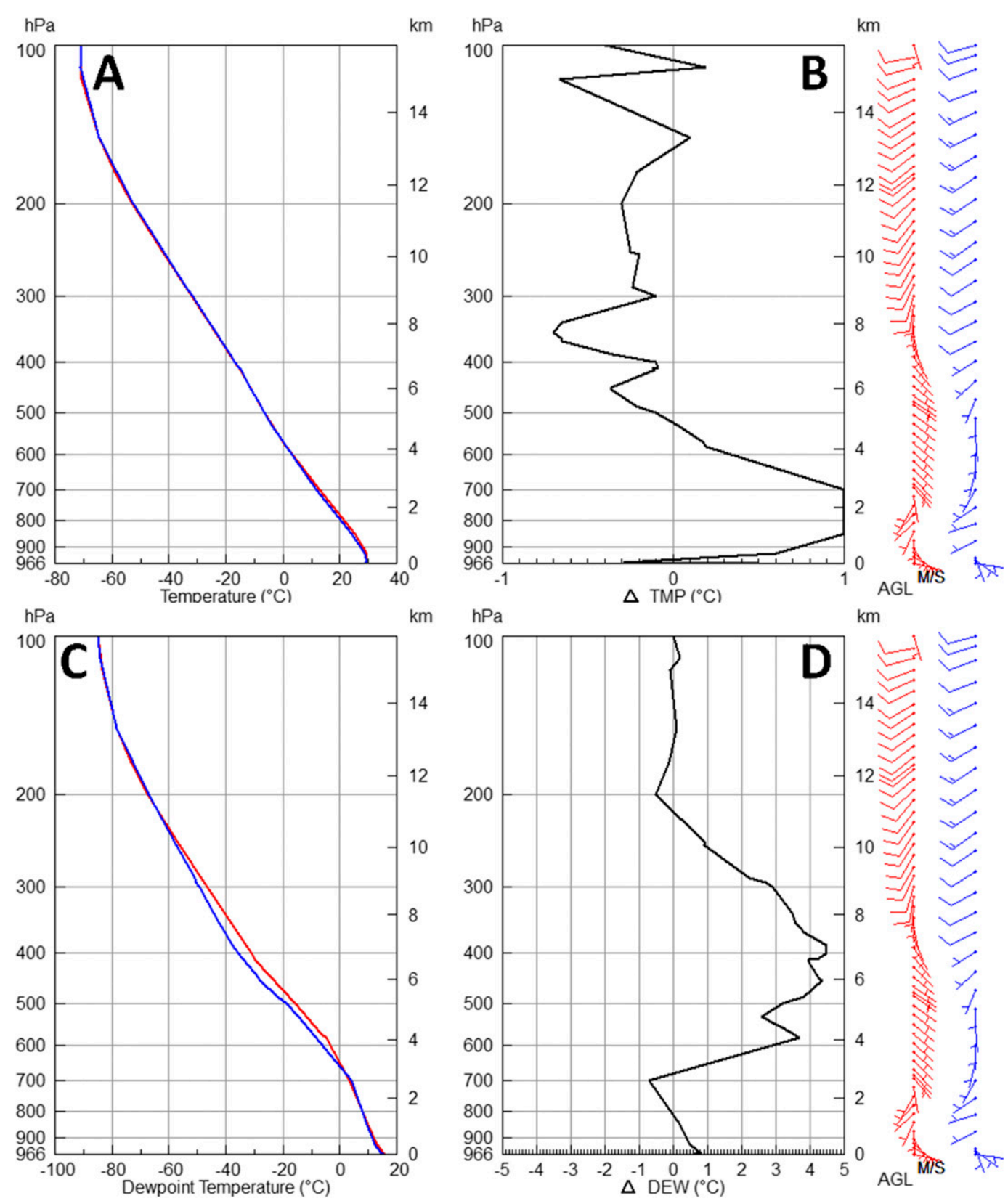

FIG. 6. Mean sounding profile comparison between Phoenix Nonattainment Area exceedance days (red) and moderate AQI days (blue) including (a) temperature, (b) temperature difference, (c) dewpoint, and (d) difference in dewpoint. (dewpoint and temperature are in ${ }^{\circ} \mathrm{C}$, wind speed in $\mathrm{m} \mathrm{s}^{-1}$, and pressure height in $\mathrm{hPa}$ ). Analyses compare 203 ozone exceedance and 444 moderate AQI cases.

rates to reduce residency time over ozone monitoring sites. Consequently, DMO8 values are low.

\section{d. Relationship with synoptic patterns}

Two overriding characteristics are found to differentiate the EXD-, MD-, and GD-type days; specifically, midlevel moisture and 700-400-hPa wind direction. Influence on these parameters originates from overlying synoptic weather patterns. The regional placement of the NAM anticyclone circulation (viz., at the 500-hPa level) plays a critical role for moisture transport creating "burst" and "break" periods in precipitation for the U.S. Southwest (Carleton 1986). The NAM circulation's relative core location to the PNA is also likely to influence dispersion patterns in the upper PBL. Therefore, 500-hPa height and 700-hPa vector winds daily 

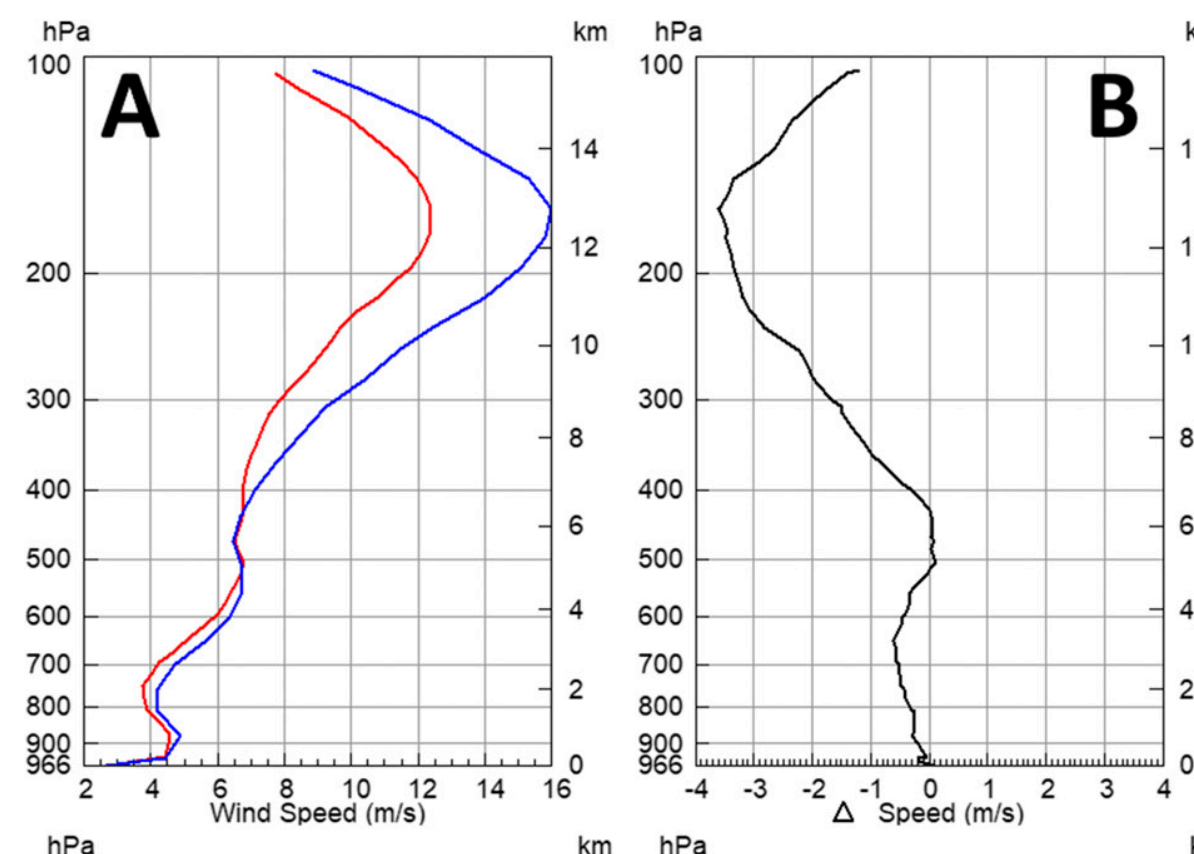

$\mathrm{km}$
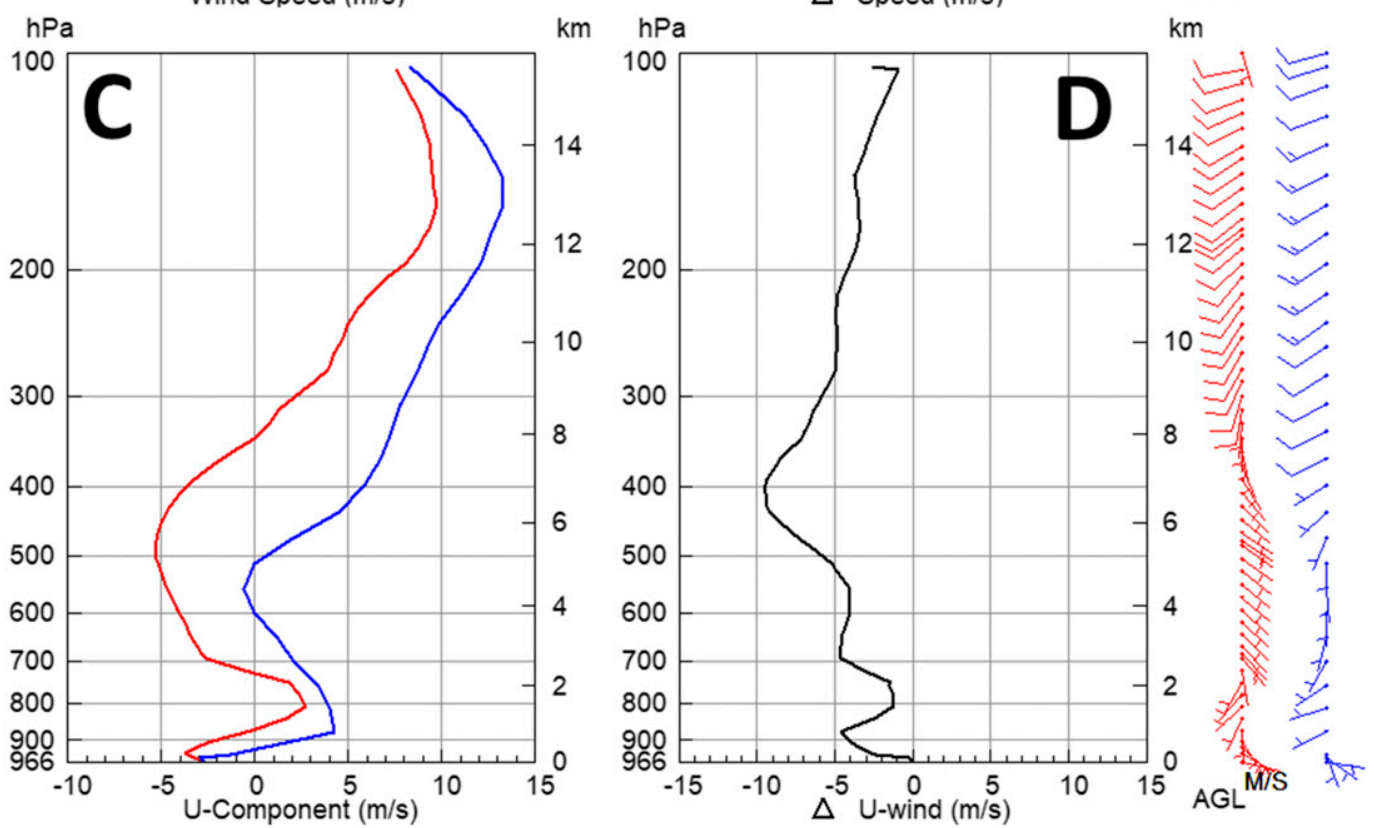

FIG. 7. Mean sounding profile comparison between Phoenix Nonattainment Area exceedance days (red) and moderate AQI days (blue) including (a) wind speed, (b) wind speed difference, (c) zonal $U$ wind component, and (d) difference in zonal wind (wind measurements are in $\mathrm{m} \mathrm{s}^{-1}$ and pressure height in hPa). Analyses compare 203 ozone exceedance and 444 moderate AQI cases.

composite plots were constructed for EXD (Figs. 11a and 11b), MD (Figs. 11c and 11d), and GD (Figs. 11e and 11f) groupings using the NARR dataset (Mesinger et al. 2006).

Results reveal three synoptic types, including 1) a relatively strong anticyclone setup over the Colorado Plateau where Utah, Arizona, Colorado, and New Mexico border ("Four Corners," Fig. 11a) for EXD days, 2) a weaker anticyclone circulation centered southeast of Phoenix near southern New Mexico for $\mathrm{MD}$, and 3) Pacific troughing intruding into the U.S. Southwest suppressing the NAM circulation well to the south and east of Phoenix. Interestingly, the Four Corners high pattern is an ideal scenario to promote advection of moisture into Arizona, leading to convection and thunderstorms. This explains why the EXD composite 
TABLE 4. Phoenix, AZ, 1200 UTC composited sounding mean and standard deviations for temperature $\left({ }^{\circ} \mathrm{C}\right)$, dewpoint $\left({ }^{\circ} \mathrm{C}\right)$, and wind speed $\left(\mathrm{m} \mathrm{s}^{-1}\right)$ at significant pressure levels $(\mathrm{hPa})$ associated with ozone good AQI days.

\begin{tabular}{|c|c|c|c|c|c|c|}
\hline \multirow[b]{2}{*}{ Pressure $(\mathrm{hPa})$} & \multicolumn{2}{|c|}{$\begin{array}{c}\text { Temperature } \\
\left({ }^{\circ} \mathrm{C}\right)\end{array}$} & \multicolumn{2}{|c|}{ Dewpoint $\left({ }^{\circ} \mathrm{C}\right)$} & \multicolumn{2}{|c|}{$\begin{array}{l}\text { Wind speed } \\
\left(\mathrm{m} \mathrm{s}^{-1}\right)\end{array}$} \\
\hline & Mean & Std dev & Mean & Std dev & Mean & Std dev \\
\hline 100 & -70.4 & 2.4 & -85.2 & 3.2 & 7.5 & 3.4 \\
\hline 150 & -64.8 & 2 & -78.6 & 4.2 & 17.1 & 8.5 \\
\hline 200 & -52.4 & 1.4 & -67.2 & 7 & 19.5 & 10.6 \\
\hline 250 & -41.2 & 1.6 & -56.9 & 9.4 & 17.1 & 9.9 \\
\hline 300 & -31.9 & 2.1 & -48.3 & 10.3 & 13.3 & 8.4 \\
\hline 400 & -16.6 & 1.8 & -35.5 & 13.3 & 9.2 & 6.2 \\
\hline 500 & -6.3 & 1.6 & -19.3 & 12.1 & 8.1 & 5.0 \\
\hline 700 & 10.5 & 1.5 & 3.9 & 4.9 & 6.7 & 3.8 \\
\hline 850 & 22.4 & 2.3 & 9.9 & 6 & 4.8 & 2.3 \\
\hline 925 & 27.2 & 2.6 & 12.3 & 6.7 & 4.5 & 2.7 \\
\hline 966 (surface) & 27.8 & 2.2 & 15.1 & 5.4 & 2.9 & 2.7 \\
\hline
\end{tabular}

sounding had higher dewpoints, at least in the midlevels of the atmosphere, compared to GD or MD days. Furthermore, this reinforces that a wind dispersion factor (speed and direction) versus moisture is likely more significant for ozone accumulation over the PNA.

The synoptic pattern over the U.S. Southwest is dynamic throughout the summer months (Adams and Comrie 1997), so it should be expected that variations in temperature, moisture, and wind occurs as the NAM circulation "wobbles." This would account for the large standard deviations in the atmosphere for each of the DMO8 categories, however, specific wind dispersion patterns seem to be necessary to allow ozone to either accumulate or disperse in the PNA. Based on the frequency and duration of EXD episodes (see Fig. 3) and GD events (Fig. 12), this study suggests there exists "pollution dispersion windows" that favor unhealthy or healthy air in Phoenix and likely the U.S. Southwest in general during the monsoon season. Evidence supports these pollution dispersion windows for good or bad air quality can be as short as a single day. Additionally, because moisture values, and therefore rainfall potential, were found to be erratic for the spectrum of DMO8 values analyzed in this study, it is likely that pollutant dispersion windows may not necessarily correspond with traditional monsoon precipitation burst and break periods.

\section{e. Relationship with diurnal atmospheric instability}

This study emphasizes the utility of using the morning 1200 UTC vertical profile to determine atmospheric conditions imminent to an ozone exceedance during the North American monsoon; however, an important consideration is the potential for significant and localized changes in the atmosphere (e.g., thunderstorm buildup and accompanying rainfall or strong gusty outflow winds) over the course of a day, especially during the portion of the day favorable for photochemical ozone production (i.e., late morning through afternoon hours). Rapid changes in local atmospheric instability are common during active periods of the monsoon season and tend to exhibit a diurnal signature, where
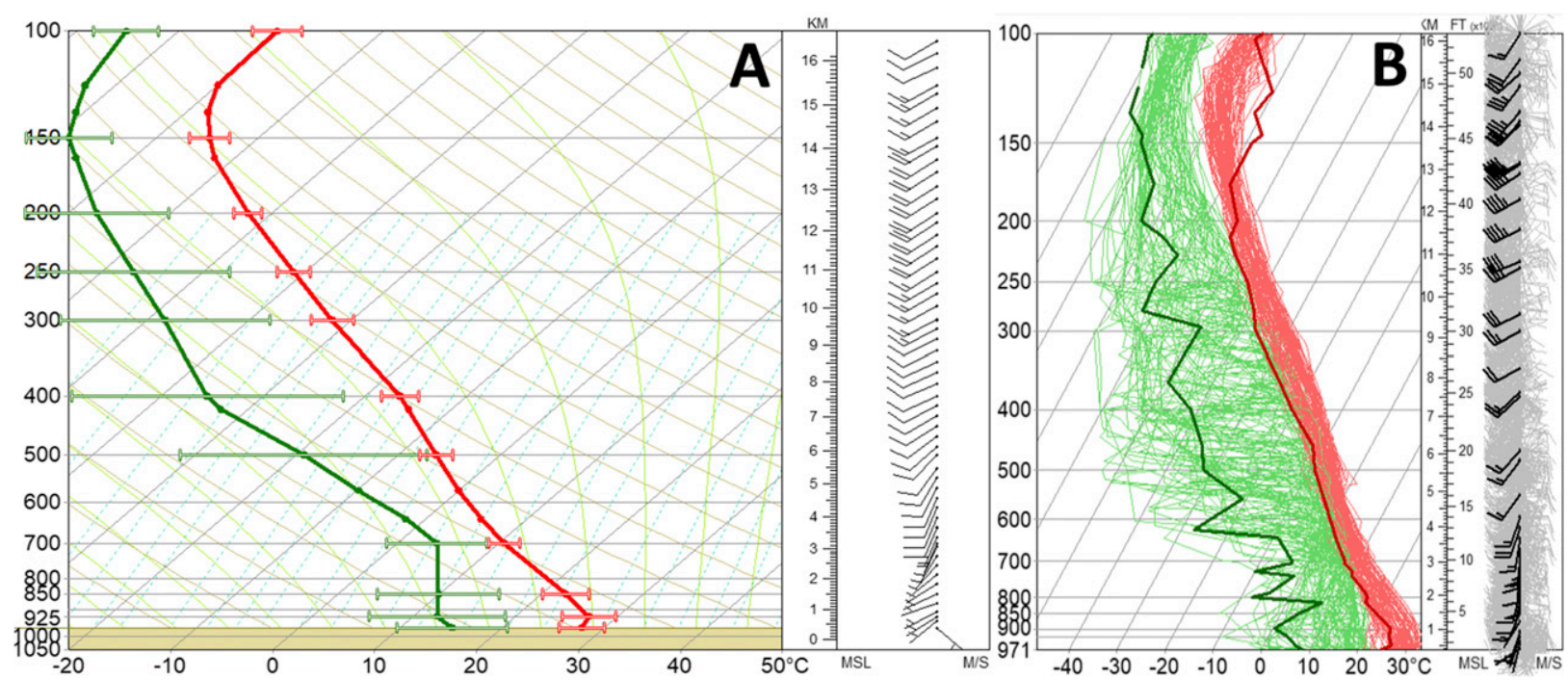

FIG. 8. (a) Mean 1200 UTC composite sounding for Phoenix ozone good AQI days (85). Standard deviation bars at significant pressure levels $(\mathrm{hPa})$ are plotted for both the dewpoint $\left({ }^{\circ} \mathrm{C}\right.$; green $)$ and temperature $\left({ }^{\circ} \mathrm{C}\right.$; red $)$ mean profiles. Mean atmospheric wind speed $\left(\mathrm{m} \mathrm{s} \mathrm{s}^{-1}\right)$ and directions are shown on right. (b) Spaghetti plot of composited soundings with the bolded dewpoint, temperature, and wind corresponding to the sounding observed on the date with the lowest DMO8 concentration (10 Jul 2015; $38 \mathrm{ppb}$ ). 

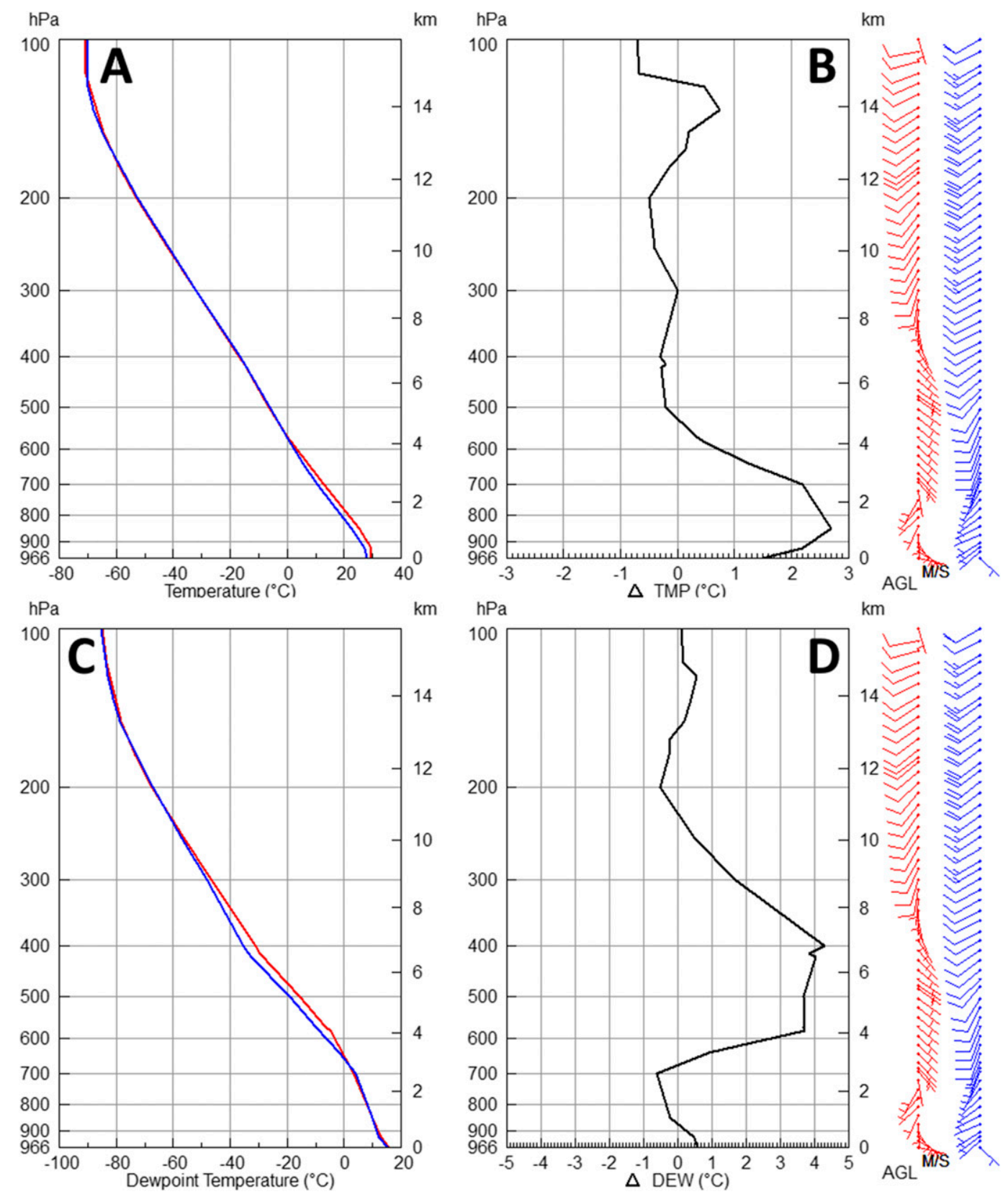

FIG. 9. Mean sounding profile comparison between Phoenix Nonattainment Area exceedance days (red) and good AQI days (blue) including (a) temperature, (b) temperature difference, (c) dewpoint, and (d) difference in dewpoint (dewpoint and temperature are in ${ }^{\circ} \mathrm{C}$, wind speed in $\mathrm{m} \mathrm{s}^{-1}$, and pressure height in $\mathrm{hPa}$ ). Analyses compare 203 ozone exceedance and 85 good AQI cases.

convection over mountainous terrain early in the day propagates toward lower desert elevations, such as the Phoenix metropolitan area, by the late afternoon and evening hours (e.g., Balling and Brazel 1987).

As the current U.S. EPA ozone measurement standard requires daily maximum 8-h averages (DMO8), forecasting the prevalence and timing of significant weather during periods of peak ozone production that may limit new ozone formation and/or disperse aged ozone would be a critical forecasting consideration in the ozone nonattainment area. To determine the association of significant weather with DMO8 values, weather observation data at Phoenix Sky Harbor International Airport (KPHX), located in the urban core of the ozone nonattainment area and in close proximity to the sounding launch location (see Fig. 1), 

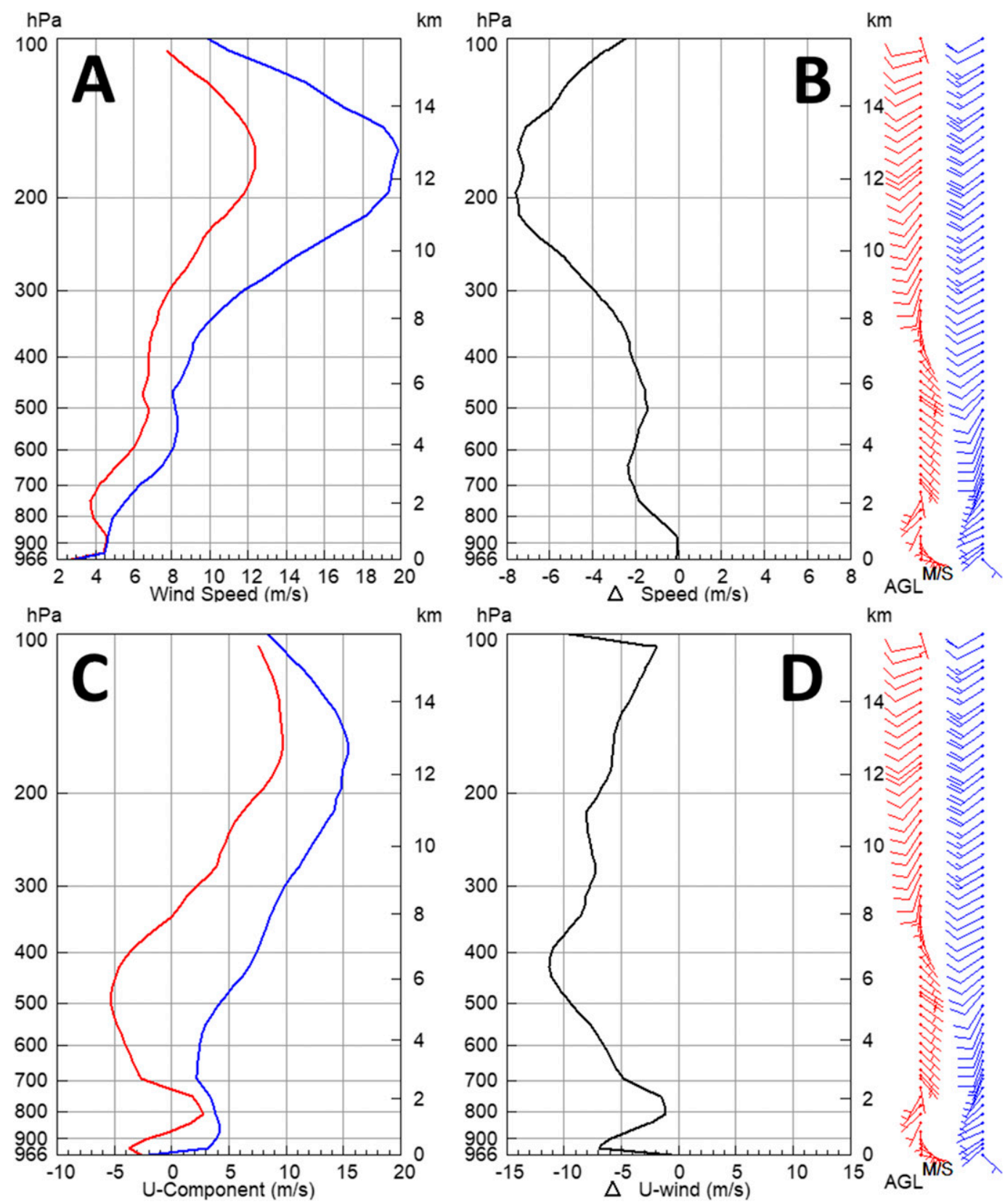

FIG. 10. Mean sounding profile comparison between Phoenix Nonattainment Area exceedance days (red) and good AQI days (blue) including (a) wind speed, (b) wind speed difference, (c) zonal $U$ wind component, and (d) difference in zonal wind (wind measurements are in $\mathrm{m} \mathrm{s}^{-1}$ and pressure height in hPa). Analyses compare 203 ozone exceedance and 85 good AQI cases.

are used to summarize daily weather conditions experienced on EXD, MD, and GD days when significant weather was or was not observed (Tables 5, 6, and 7 , respectively). Additionally, the frequency of an easterly wind component at the 500- and $700-\mathrm{hPa}$ pressure levels is compared, since this has been found to be prevalent on days with higher ozone concentrations.
An important finding is apparent when considering the frequency and timing of significant weather observed at KPHX for the three study-defined daily ozone concentration categories (EXD, MD, and GD). That is, that active monsoon weather and rainfall (when including trace amounts) have occurred for nearly a third of the cases in each respective ozone category. Additionally, an easterly flow in the 1200 UTC vertical profile 


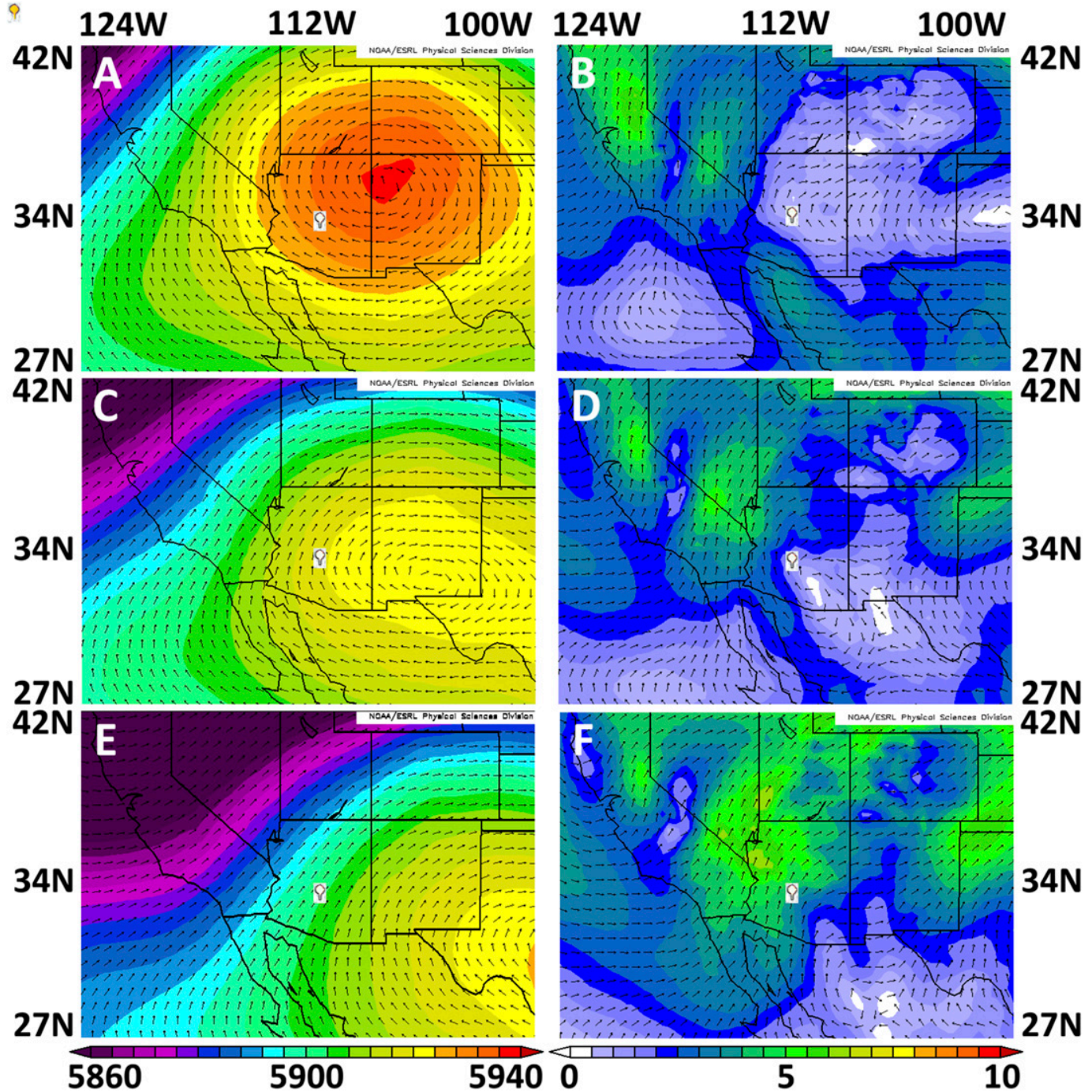

FIG. 11. Daily mean (left) 500-hPa height (m) and (right) 700-hPa vector wind speed ( $\mathrm{m} \mathrm{s}^{-1}$ ) plots for Phoenix (a),(b) ozone exceedance days (203); (c),(d) moderate AQI days (444); and (e),(f) good AQI days (85). For reference, the Phoenix sounding launch location is $33.45^{\circ} \mathrm{N}, 111.95^{\circ} \mathrm{W}$ and is marked by a white balloon. Images provided by the NOAA/ESRL Physical Science Division (2018).

at 500- and 700-hPa pressure levels has been found to be associated with a majority of both EXD and MD days experiencing significant weather (see Tables 5 and 6 ). Easterly and southerly flow in the middle and lower levels of the atmosphere (i.e., 500 and $700 \mathrm{hPa}$ ) aligns with a documented favored monsoon synoptic setup importing moisture to increase coverage of convective activity in Arizona (e.g., Maddox et al. 1995).

Specifically for the EXD category, the daily presence of rainfall or localized atmospheric instability (e.g., thunderstorm or gusty winds) does not preclude an ozone exceedance; however, relative to the timing of significant weather observations versus MD days, the presence of active weather is rare during the key photochemical period between the late morning and afternoon (i.e., only 12 of 206 EXD cases). Furthermore, the average daily maximum $1-\mathrm{h}$ ozone concentrations (see "DMO1" on Table 5) on EXD days are comparable whether active weather is observed or not (i.e., $89.4 \mathrm{ppb}$ in 64 cases vs 87.9 ppb in 142 cases, respectively). This suggests an environment supportive of higher ozone may be present, yet the timing of monsoon convective impacts overlapping with the afternoon hours in the ozone nonattainment area could cap DMO8 value potential and prevent exceedance levels. Even, a few hours reduction in the maximum daily 8 -h ozone average due to daytime thunderstorm influences could be the difference between a day classified as EXD or MD. This 


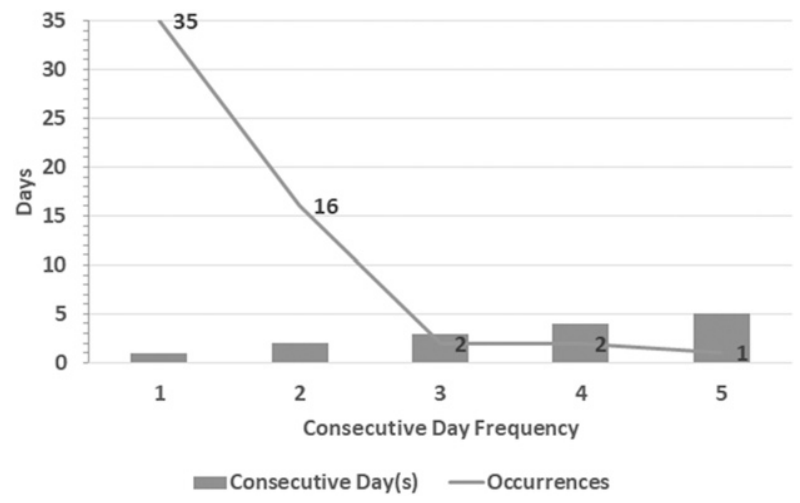

FIG. 12. Ozone good AQI day episode duration frequency for the Phoenix Nonattainment Area during the months of July and August (2006-17). Analysis includes 85 good AQI cases.

provides evidence for a timing aspect of monsoon active weather being significant to allow (or limit) ozone concentrations reaching and maintaining higher concentrations over the daytime hours to cause a DMO8 exceedance. Timing of convection should be seen as an important factor for air quality forecasting purposes.
Indication for imminent rapidly changing atmospheric conditions would be a limitation when only using the 1200 UTC vertical atmospheric profile to anticipate DMO8 ozone concentrations during the later morning through afternoon hours.

Another aspect reviewed was surface temperature as prior studies have shown positive correlations between ozone and temperature (e.g., Carro-Calvo et al. 2017; Saini et al. 2017); therefore, changing trends in temperatures in the Phoenix Nonattainment Area could be a driver for ozone exceedances. Consequently, maximum, minimum, and daily average temperature data at KPHX were reviewed but did not show significant trends for the July and August period (2006-17). Additionally, temperature data indicate a wide variability amongst three ozone classifications used in this study with overlap between exceedance and nonexceedance days. Tables 5, 6, and 7 show the wide ranges in temperature (and other meteorological variables over the range of ozone classifications).

Along with a lack of a significant temperature trend found at KPHX, the range in ozone exceedance days for

TABLE 5. For ozone EXD days, the daily surface weather conditions (temperature and dewpoint are ${ }^{\circ} \mathrm{C}$; wind speed is $\mathrm{m} \mathrm{s}^{-1}$ ) at Phoenix Sky Harbor International Airport (KPHX), 1200 UTC 500- and 700-hPa wind direction, DMO8, and DMO1 compared when significant weather was or was not observed at KPHX. A "significant weather observation day" is defined as any day indicating active weather having at least one hourly observation of thunderstorm, thunderstorm in vicinity, rain, showers, squalls, or dust. For reference, KPHX observations occur at $33.42^{\circ} \mathrm{N}, 112.00^{\circ} \mathrm{W}$ and are in close proximity to the Phoenix sounding launch location $\left(33.45^{\circ} \mathrm{N}, 111.95^{\circ} \mathrm{W}\right)$. There is a total of 206 EXD days in the months of July and August (2006-17), with 500- and 700-hPa sounding availability limited to 203 days. Units for ozone are parts per billion ( $\mathrm{ppb}$ ), and pressure is hectopascals $(\mathrm{hPa})$. Surface weather observations were obtained from the National Oceanic and Atmospheric Administration National Centers for Environmental Information's "Local Climatological Data" dataset.

\begin{tabular}{|c|c|c|c|c|}
\hline \multirow[b]{2}{*}{ Parameter } & \multicolumn{2}{|c|}{ Significant weather observed } & \multicolumn{2}{|c|}{ Non-significant weather observed } \\
\hline & Daily count or (mean) & Proportion or (range) & Daily count or (mean) & Proportion or (range) \\
\hline Non-significant weather observation day & - & - & 142 & 68.9 \\
\hline Significant weather observation day & 64 & 31.1 & - & - \\
\hline Significant weather day (0551-1051 LST) & 7 & 3.4 & - & - \\
\hline Significant weather day (1151-1851 LST) & 12 & 5.8 & - & - \\
\hline Significant weather day (1951-0451 LST) & 49 & 23.8 & - & - \\
\hline Measurable rain day & 31 & 15.0 & - & - \\
\hline Trace precipitation day & 31 & 15.0 & - & - \\
\hline DMO8 & $(76.6)$ & $(71-89)$ & $(75.9)$ & $(71-96)$ \\
\hline DMO1 & $(89.4)$ & $(75-109)$ & $(87.9)$ & $(75-122)$ \\
\hline 500-hPa easterly zonal wind & 47 & 74.6 & 77 & 55.0 \\
\hline 500-hPa westerly zonal wind & 16 & 25.4 & 63 & 45.0 \\
\hline $500-\mathrm{hPa}$ northerly meridional wind & 23 & 36.5 & 51 & 36.4 \\
\hline 500-hPa southerly meridional wind & 40 & 63.5 & 89 & 63.6 \\
\hline 700-hPa easterly zonal wind & 45 & 71.4 & 79 & 56.4 \\
\hline 700-hPa westerly zonal wind & 18 & 28.6 & 61 & 43.6 \\
\hline 700-hPa northerly meridional wind & 20 & 31.7 & 62 & 44.3 \\
\hline 700-hPa southerly meridional wind & 43 & 68.3 & 78 & 55.7 \\
\hline Daily maximum temperature & $(41.3)$ & $(35-48)$ & $(42.4)$ & $(36-48)$ \\
\hline Daily mean temperature & (35) & $(28-40)$ & $(36.4)$ & $(31-41)$ \\
\hline Daily minimum temperature & $(28.4)$ & $(18-34)$ & $(30.2)$ & $(24-35)$ \\
\hline Daily mean dewpoint & $(15.4)$ & $(6-21)$ & (13) & $(-2$ to 20$)$ \\
\hline Daily mean wind speed & (3.4) & $(2-5)$ & (3) & $(2-5)$ \\
\hline Daily peak wind speed & $(15.7)$ & $(8-34)$ & $(10.7)$ & $(6-20)$ \\
\hline
\end{tabular}


TABLE 6. For ozone moderate AQI days (MD), the daily surface weather conditions (temperature and dewpoint are ${ }^{\circ} \mathrm{C}$; wind speed is $\mathrm{m} \mathrm{s}^{-1}$ ) at Phoenix Sky Harbor International Airport (KPHX), 1200 UTC 500- and 700-hPa wind direction, DMO8, and DMO1 compared when significant weather was or was not observed at KPHX. A "significant weather observation day" is defined as any day indicating active weather having at least one hourly observation of thunderstorm, thunderstorm in vicinity, rain, showers, squalls, or dust. For reference, KPHX observations occur at $33.42^{\circ} \mathrm{N}, 112.00^{\circ} \mathrm{W}$ and are in close proximity to the Phoenix sounding launch location $\left(33.45^{\circ} \mathrm{N}\right.$, $\left.111.95^{\circ} \mathrm{W}\right)$. There is a total of $453 \mathrm{MD}$ days in the months of July and August (2006-17), with 500- and 700-hPa sounding availability limited to 440 and 442 days, respectively. Units for ozone are parts per billion (ppb), and pressure is hectopascals (hPa). Surface weather observations were obtained from the National Oceanic and Atmospheric Administration National Centers for Environmental Information's "Local Climatological Data" dataset.

\begin{tabular}{|c|c|c|c|c|}
\hline \multirow[b]{2}{*}{ Parameter } & \multicolumn{2}{|c|}{ Significant weather observed } & \multicolumn{2}{|c|}{ Non-significant weather observed } \\
\hline & Daily count or (mean) & Proportion or (range) & Daily count or (mean) & Proportion or (range) \\
\hline Non-significant weather observation day & - & - & 327 & 72.2 \\
\hline Significant weather observation day & 126 & 27.8 & - & - \\
\hline Significant weather day (0551-1051 LST) & 18 & 7.1 & - & - \\
\hline Significant weather day (1151-1851 LST) & 39 & 15.4 & - & - \\
\hline Significant weather day (1951-0451 LST) & 92 & 36.4 & - & - \\
\hline Measurable rain day & 69 & 27.3 & - & - \\
\hline Trace precipitation day & 64 & 25.3 & - & - \\
\hline DMO8 & $(63.2)$ & $(55-70)$ & $(62.8)$ & $(55-70)$ \\
\hline DMO1 & $(73.3)$ & $(55-94)$ & $(73.9)$ & $(58-95)$ \\
\hline 500-hPa easterly zonal wind & 80 & 66.1 & 121 & 37.9 \\
\hline 500-hPa westerly zonal wind & 41 & 33.9 & 198 & 62.1 \\
\hline 500-hPa northerly meridional wind & 39 & 32.2 & 103 & 32.3 \\
\hline 500-hPa southerly meridional wind & 82 & 67.8 & 216 & 67.7 \\
\hline 700-hPa easterly zonal wind & 68 & 56.2 & 112 & 34.9 \\
\hline 700-hPa westerly zonal wind & 53 & 43.8 & 209 & 65.1 \\
\hline 700-hPa northerly meridional wind & 52 & 43.0 & 92 & 28.7 \\
\hline 700-hPa southerly meridional wind & 69 & 57.0 & 229 & 71.3 \\
\hline Daily maximum temperature & $(39.9)$ & $(32-46)$ & $(41.5)$ & $(33-48)$ \\
\hline Daily mean temperature & $(33.8)$ & $(28-40)$ & $(35.7)$ & $(30-41)$ \\
\hline Daily minimum temperature & $(27.5)$ & $(22-34)$ & $(29.7)$ & $(24-35)$ \\
\hline Daily mean dewpoint & $(16.7)$ & $(8-22)$ & (12.1) & $(-4$ to 21$)$ \\
\hline Daily mean wind speed & $(3.5)$ & $(2-6)$ & $(3.2)$ & $(2-6)$ \\
\hline Daily peak wind speed & $(15.7)$ & $(7-31)$ & $10.9)$ & $(7-21)$ \\
\hline
\end{tabular}

the July and August period is as low as 6 occurrences in 2010 and as high as 30 in 2016 . There have also been as high as 25 as late as 2012 and most recently, 14 in 2017. This variability likely means temperature is not the driving factor for ozone exceedances in the nonattainment area. However, Bonn et al. (2018) did find a temperature dependency on isoprene and monoterpenes produced from trees in an urban environment that affects contribution and reduction of ozone. It should be noted that potential ozone influences on vegetation type and coverage in the Phoenix metropolitan area are not addressed in this study and is a limitation using vertical atmospheric sounding profiles alone to forecast ozone.

An additional limitation using only vertical atmospheric sounding profiles to forecast ozone concentration is that this tool would not explicitly account for impacts from wildfires, specifically wildfire smoke. Research by Kang et al. (2014) found wildfire smoke plumes contain ozone precursors that influence regional background ozone levels. This has also been confirmed by others studies (e.g., Baker et al. 2016, 2018; Jaffe and
Wigder 2012). Since long-range transport of ozone aloft has potential to down-mix (or fumigate) toward the surface (e.g., VanCuren 2015), it likely that wildfireinfluenced ozone could be a factor in observed ozone concentrations in the PNA. Although not investigated in this study, it is reasoned that the onset of the monsoon for the months of July and August bringing higher relative humidity and rainfall would limit significant wildfire activity in and around the ozone nonattainment area and, therefore, ozone contribution from wildfires would be reduced.

Despite these limitations inherent with using vertical in situ sounding data, this technique of composite sounding analysis does have several advantages for forecasting ozone potential in the PNA. First, it uses the actual observations prior to an exceedance as its primary data. This technique thereby improves forecasting ability by allowing the forecaster to assess their current atmospheric situation prior to an exceedance against the past known ensemble of exceedance event soundings shown by composite analyses completed for different 
TABLE 7. For ozone good AQI days (GD), the daily surface weather conditions (temperature and dewpoint are ${ }^{\circ} \mathrm{C}$; wind speed is $\mathrm{m} \mathrm{s}{ }^{-1}$ ) at Phoenix Sky Harbor International Airport (KPHX), 1200 UTC 500- and 700-hPa wind direction, DMO8, and DMO1 compared when significant weather was or was not observed at KPHX. A "significant weather observation day" is defined as any day indicating active weather having at least one hourly observation of thunderstorm, thunderstorm in vicinity, rain, showers, squalls, or dust. For reference, KPHX observations occur at $33.42^{\circ} \mathrm{N}, 112.00^{\circ} \mathrm{W}$ and are in close proximity to the Phoenix sounding launch location $\left(33.45^{\circ} \mathrm{N}, 111.95^{\circ} \mathrm{W}\right)$. There is a total of 85 GD days in the months of July and August (2006-17), with 500- and 700-hPa sounding availability limited to 82 days. Units for ozone are parts per billion (ppb), and pressure is hectopascals (hPa). Surface weather observations were obtained from the National Oceanic and Atmospheric Administration National Centers for Environmental Information's "Local Climatological Data" dataset.

\begin{tabular}{|c|c|c|c|c|}
\hline \multirow[b]{2}{*}{ Parameter } & \multicolumn{2}{|c|}{ Significant weather observed } & \multicolumn{2}{|c|}{ Non-significant weather observed } \\
\hline & Daily count or (mean) & Proportion or (range) & Daily count or (mean) & Proportion or (range) \\
\hline Non-significant weather observation day & - & - & 58 & 68.2 \\
\hline Significant weather observation day & 27 & 31.8 & - & - \\
\hline Significant weather day (0551-1051 LST) & 7 & 8.2 & - & - \\
\hline Significant weather day (1151-1851 LST) & 16 & 18.8 & - & - \\
\hline Significant weather day (1951-0451 LST) & 18 & 21.2 & - & - \\
\hline Measurable rain day & 20 & 23.5 & - & - \\
\hline Trace precipitation day & 8 & 9.4 & - & - \\
\hline DMO8 & $(49.2)$ & $(41-54)$ & $(49.4)$ & $(38-54)$ \\
\hline DMO1 & $(56.5)$ & $(45-73)$ & $(57.2)$ & $(41-76)$ \\
\hline 500-hPa easterly zonal wind & 13 & 50.0 & 16 & 28.6 \\
\hline 500-hPa westerly zonal wind & 13 & 50.0 & 40 & 71.4 \\
\hline 500-hPa northerly meridional wind & 7 & 26.9 & 11 & 19.6 \\
\hline $500-\mathrm{hPa}$ southerly meridional wind & 19 & 73.1 & 45 & 80.4 \\
\hline 700-hPa easterly zonal wind & 11 & 42.3 & 16 & 28.6 \\
\hline 700-hPa westerly zonal wind & 15 & 57.7 & 40 & 71.4 \\
\hline 700-hPa northerly meridional wind & 6 & 23.1 & 8 & 14.3 \\
\hline 700-hPa southerly meridional wind & 20 & 76.9 & 48 & 85.7 \\
\hline Daily maximum temperature & $(36.2)$ & $(31-42)$ & $(40)$ & $(31-44)$ \\
\hline Daily mean temperature & $(31.2)$ & $(27-37)$ & $(34.5)$ & $(28-37)$ \\
\hline Daily minimum temperature & $(25.8)$ & $(22-32)$ & $(28.8)$ & $(22-33)$ \\
\hline Daily mean dewpoint & $(18.3)$ & $(8-22)$ & $(11.2)$ & $(-4$ to 19$)$ \\
\hline Daily mean wind speed & $(3.3)$ & $(2-4)$ & $(3.4)$ & $(2-6)$ \\
\hline Daily peak wind speed & $(17.4)$ & $(6-21)$ & $(11.1)$ & $(8-18)$ \\
\hline
\end{tabular}

ozone concentration categories. While atmospheric weather models may also provide a means of forecasting exceedance events, they are limited by the quality/ resolution of the digital terrain used in the model and by the ability of the model to resolve known features of the region such as convective precipitation, particularly given the complex topography of the intermountain region of the Southwest (e.g., Wang et al. 2009). Second, the use of sounding data allows the forecaster to view the entire atmospheric profile as opposed to specific individual variables (Malloy 2018), thereby potentially achieving a better gestalt of the complete situation. Third, composite soundings provide a vertical view of a given exceedance situation that can work in harmony with synoptic map (horizontal) analysis.

Therefore, this type of technique can be potentially made operational by using solely statistical comparative techniques in an analog-style forecast or applying regression analysis in a model output statistics style. For example, with regard to the latter, a study of winter persistent inversions in the Intermountain region demonstrated that simple regression techniques could be applied to climate models' geopotential height data as a means of forecasting persistent inversions to perhaps lead-times of up to four weeks (Gillies et al. 2010b). A similar possibility exists here by identifying particular composite features of soundings and applying them to output from high-resolution models [e.g., Weather Research and Forecasting (WRF) Model]. However, given the transitive nature of the NAM, it is likely that such a coupled sounding-model analysis would have likely markedly less lead time than studies such as Gillies et al. (2010a).

\section{Conclusions}

Composite analysis of monsoonal July-August atmospheric soundings for the Phoenix Nonattainment Area (PNA) over the period 2006-17 revealed that a large variability exists in vertical atmospheric conditions over the course of the North American monsoon (NAM) and that higher surface ozone concentrations 
are possible for the PNA under numerous types of atmospheric combinations of moisture and temperature.

First, when reviewing soundings, wind characteristics appear to be a more reliable indicator than either moisture or temperature for an ideal atmosphere conducive for ozone accumulation. Specifically, light wind regimes with an easterly component between the upper PBL and midlevels of the atmosphere are prevalent based on the mean exceedance day composite sounding, while deep and faster westerly flow forces lower ozone concentrations.

Second, general synoptic patterns were found for good, moderate, and exceeding air quality index (AQI) days. These patterns play a role for dictating large-scale wind patterns and hence ozone accumulation potential for the Phoenix metropolitan area.

Third, a "Four Corners high" position (central Colorado Plateau) of the monsoon midlevel circulation was identified as a favorable synoptic setup for higher DMO8 values, despite a flow pattern that would be conducive for moisture transport into the PNA. On the other hand, closer proximity to Pacific troughing enhances dispersion of ozone at both the surface and aloft. Consequently, analogous to precipitation "bursts" and "breaks" this study has determined "pollution dispersion windows" that provide a conceptual model framework for general air quality expectations.

Fourth, throughout the study period, single day ozone exceedance occurs at a much higher frequency versus longer durations, suggesting that even short day-to-day migration of the monsoon circulation are important for pollutant potential in this region. Additionally, using the U.S. EPA's current threshold for healthy air (DMO8 $\leq$ $55 \mathrm{ppb}$ ), the months of July and August rarely see atmospheric conditions supportive of high dispersion rates (i.e., deep westerly flow) sufficient enough declare a good AQI day.

Finally, although a light easterly synoptic flow relative to Phoenix's unique topography is significant for locally unhealthful ozone levels, it is suspected, but not confirmed in this study, that a deep westerly flow pattern associated with Pacific troughing causes a regional decrease in ozone levels for urbanized areas due to higher dispersion rates. However, background ozone concentrations downwind of these urban sites may increase due to transport mixing mechanisms.

Findings presented in this study demonstrate composite sounding analysis is a viable and useful forecasting technique for air quality applications. Results are expected to be particularly pertinent to air quality meteorologists responsible for disseminating ozone forecasts within and in proximity to the Phoenix Nonattainment Area.
Acknowledgments. The authors thank three anonymous reviewers for their constructive comments and suggestion that ultimately improved the content of this research.

\section{REFERENCES}

Adams, D. K., and A. C. Comrie, 1997: The North American monsoon. Bull. Amer. Meteor. Soc., 78, 2197-2213, https:// doi.org/10.1175/1520-0477(1997)078<2197:TNAM >2.0.CO;2.

ADEQ, 2018: State of Arizona air monitoring network plan for the year 2018. Arizona Department of Environmental Quality (ADEQ), accessed 25 March 2019, 124 pp., http://static.azdeq.gov/ aqd/air_monitoring_network_plan2018.pdf.

Atkinson-Palombo, C. M., J. A. Miller, and R. C. Balling, 2006: Quantifying the ozone "weekend effect" at various locations in Phoenix, Arizona. Atmos. Environ., 40, 7644-7658, https:// doi.org/10.1016/j.atmosenv.2006.05.023.

Baker, K. R., M. C. Woody, G. S. Tonnesen, W. Hutzell, H. O. T. Pye, M. R. Beaver, G. Pouliout, and T. Pierce, 2016: Contribution of regional-scale fire events to ozone and $\mathrm{PM}_{2.5}$ air quality estimated by photochemical modeling approaches. Atmos. Environ., 140, 539-554, https://doi.org/10.1016/ j.atmosenv.2016.06.032.

, and Coauthors, 2018: Photochemical model evaluation of 2013 California wild fire air quality impacts using surface, aircraft, and satellite data. Sci. Total Environ., 637-638, 11371149, https://doi.org/10.1016/j.scitotenv.2018.05.048.

Balling, R. C., Jr., and S. W. Brazel, 1987: Recent changes in Phoenix, Arizona summertime diurnal precipitation patterns. Theor. Appl. Climatol., 38, 50-54, https://doi.org/10.1007/ BF00866253.

Bonn, B., and Coauthors, 2018: Impact of vegetative emissions on urban ozone and biogenic secondary organic aerosol: Box model study for Berlin, Germany. J. Clean. Prod., 176, 827841, https://doi.org/10.1016/j.jclepro.2017.12.164.

Brazel, A. J., and W. G. Nickling, 1986: The relationship of weather types to dust storm generation in Arizona (1965-1980). J. Climatol., 6, 255-275, https://doi.org/10.1002/joc.3370060303.

Carleton, A. M., 1986: Synoptic-dynamic character of "bursts" and "breaks" in the southwest U.S. summer precipitation singularity. J. Climatol., 6, 605-623, https://doi.org/10.1002/joc.3370060604.

Carro-Calvo, L., C. Ord, C. Ordóñeza, R. García-Herrera, and J. L. Schnell, 2017: Spatial clustering and meteorological drivers of summer ozone in Europe. Atmos. Environ., 167, 496-510, https://doi.org/10.1016/j.atmosenv.2017.08.050.

Diem, J., and D. Brown, 2009: Relationships among monsoonseason circulation patterns, gulf surges, and rainfall within the Lower Colorado River Basin, USA. Theor. Appl. Climatol., 97, 373-383, https://doi.org/10.1007/s00704-008-0081-x.

Douglas, M. W., R. A. Maddox, K. Howard, and S. Reyes, 1993: The Mexican monsoon. J. Climate, 6, 1665-1677, https:// doi.org/10.1175/1520-0442(1993)006<1665:TMM >2.0.CO;2.

Ellis, A. W., M. L. Hildebrandt, and H. J. S. Fernando, 1999: Evidence of lower-atmospheric ozone "sloshing" in an urbanized valley. Phys. Geogr., 20, 520-536, https://doi.org/10.1080/ 02723646.1999.10642694.

, - — W. H. Thomas, and H. J. S. Fernando, 2000: Analysis of the climatic mechanisms contributing to the summertime transport of lower atmospheric ozone across metropolitan Phoenix, Arizona, USA. Climate Res., 15, 13-31, https://doi.org/ $10.3354 / \mathrm{cr} 015013$ 
_, E. M. Saffell, and T. W. Hawkins, 2004: Method for defining monsoon onset and demise in the Southwestern USA. Int. J. Climatol., 24, 247-265, https://doi.org/10.1002/joc.996.

Fast, J. D., J. C. Doran, W. J. Shaw, R. L. Coulter, and T. J. Martin, 2000: The evolution of the boundary layer and its effect on air chemistry in the Phoenix area. J. Geophys. Res., 105, 22833 22 848, https://doi.org/10.1029/2000JD900289.

Fawbush, M., R. Miller, and L. Starrett, 1951: An empirical method of forecasting tornado development. Bull. Amer. Meteor. Soc., 32, 1-9, https://doi.org/10.1175/1520-0477-32.1.1.

Gillies, R. R., S.-Y. Wang, and M. R. Booth, 2010a: Atmospheric scale interaction on wintertime Intermountain West low-level inversion. Wea. Forecasting, 25, 1196-1210, https://doi.org/ 10.1175/2010WAF2222380.1.

—_, — _ J.-H. Yoon, and S. Weaver, 2010b: CFS prediction of winter persistent inversions in the intermountain region. Wea. Forecasting, 25, 1211-1218, https://doi.org/10.1175/ 2010WAF2222419.1.

Gold, D. R., G. Allen, A. Damokosh, P. Serrano, C. Hayes, and M. Castillejos, 1996: Comparison of outdoor and classroom ozone exposures for school children in Mexico City. J. Air Waste Manag. Assoc., 46, 335-342.

Heinselman, P. L., and D. M. Schultz, 2006: Intraseasonal variability of summer storms over central Arizona during 1997 and 1999. Wea. Forecasting, 21, 559-578, https://doi.org/10.1175/WAF929.1.

Jaffe, D. A., and L. Wigder, 2012: Ozone production from wildfires: A critical review. Atmos. Environ., 51, 1-10, https://doi.org/ 10.1016/j.atmosenv.2011.11.063.

Kang, C.-M., D. Gold, and P. Koutrkis, 2014: Downwind $\mathrm{O}_{3}$ and $\mathrm{PM}_{2.5}$ speciation during the wildfires in 2002 and 2010. Atmos. Environ., 95, 511-519, https://doi.org/10.1016/ j.atmosenv.2014.07.008.

King, T. S., and R. C. Balling, 1994: Diurnal-variations in Arizona monsoon lightning data. Mon. Wea. Rev., 122, 1659-1664, https:// doi.org/10.1175/1520-0493(1994)122<1659:DVIAML>2.0.CO;2.

Lee, S. M., and H. J. S. Fernando, 2013: Dispersion of an urban photochemical plume in Phoenix metropolitan area. Atmos. Environ., 80, 152-160, https://doi.org/10.1016/j.atmosenv.2013.07.066.

,-- M. Princevac, D. Zajic, M. Sinesi, J. L. McCulley, and J. Anderson, 2003: Transport and diffusion of ozone in the nocturnal and morning planetary boundary layer of the Phoenix valley. Environ. Fluid Mech., 3, 331-362, https:// doi.org/10.1023/A:1023680216173.

Maddox, R. A., D. M. McCollum, and K. W. Howard, 1995: Largescale patterns associated with severe summertime thunderstorms over central Arizona. Wea. Forecasting, 10, 763-778, https://doi.org/10.1175/1520-0434(1995)010<0763:LSPAWS > 2.0.CO;2.

Malloy, J. W., 2011: Using atmospheric profiles to forecast sever hail events in northern Arizona during the North American Monsoon season. J. Ariz.-Nev. Acad. Sci., 43, 16-26, https:// doi.org/10.2181/036.043.0104.

_ 2018: Atmospheric patterns in relationship with observed ozone concentrations in the Phoenix, Arizona, metropolitan area during the North American Monsoon. Atmos. Environ., 191, 64-69, https://doi.org/10.1016/j.atmosenv.2018.08.001.

Mesinger, F., and Coauthors, 2006: North American Regional Reanalysis. Bull. Amer. Meteor. Soc., 87, 343-360, https:// doi.org/10.1175/BAMS-87-3-343.

Mills, G., H. Harmens, S. Wagg, K. Sharps, F. Hayes, D. Fowler, M. Sutton, and B. Davies, 2016: Ozone impacts on vegetation in a nitrogen enriched and changing climate. Environ. Pollut., 208, 898-908, https://doi.org/10.1016/j.envpol.2015.09.038.
Mullen, S. L., J. T. Schmitz, and N. O. Renno, 1998: Intraseasonal variability of the summer monsoon over southeast Arizona. Mon. Wea. Rev., 126, 3016-3035, https://doi.org/10.1175/15200493(1998)126<3016:IVOTSM >2.0.CO;2.

NOAA/ESRL Physical Science Division, 2018: NOAA/ESRL Physical Science Division, Boulder, CO, accessed 4 October 2018, http://www.esrl.noaa.gov/psd/.

Owens, E. O., M. M. Patel, E. Kirrane, T. C. Long, J. Brown, I. Cote, M. A. Ross, and S. J. Dutton, 2017: Framework for assessing causality of air pollution-related health effects for reviews of the National Ambient Air Quality Standards. Regul. Toxicol. Pharmacol., 88, 332-337, https://doi.org/10.1016/ j.yrtph.2017.05.014.

Quincey, P., D. Butterfield, H. D'Souza, and M. Henderson, 2007: Monitoring of ozone precursors in ambient air using pumped and diffusive sampling on the sorbent Carbopack X. Atmos. Environ., 41, 7865-7873, https://doi.org/10.1016/ j.atmosenv.2007.06.063.

Rodriguez, C. A. M., R. P. da Rocha, and R. Bombardi, 2010: On the development of summer thunderstorms in the city of Sao Paulo: Mean meteorological characteristics and pollution effect. Atmos. Res., 96, 477-488, https://doi.org/10.1016/ j.atmosres.2010.02.007.

Saini, R., A. Taneja, and P. Singh, 2017: Surface ozone scenario and air quality in the north-central part of India. J. Environ. Sci. (China), 59, 72-79, https://doi.org/10.1016/j.jes.2017.02.008.

Schrage, J. M., S. Augustyn, and A. H. Fink, 2007: Nocturnal stratiform cloudiness during the West African monsoon. Meteor. Atmos. Phys., 95, 73-86, https://doi.org/10.1007/ s00703-006-0194-7.

Shi, C. N., H. J. S. Fernando, and P. Hyde, 2012: CMAQ predictions of tropospheric ozone in the US southwest: Influence of lateral boundary and synoptic conditions. Sci. Total Environ., 416, 374 384, https://doi.org/10.1016/j.scitotenv.2011.12.025.

Sugimoto, S., T. Sato, and K. Nakamura, 2013: Effects of synopticscale control on long-term declining trends of summer fog frequency over the Pacific side of the Hokkaido Island. J. Appl. Meteor. Climatol., 52, 2226-2242, https://doi.org/ 10.1175/JAMC-D-12-0192.1.

U.S. Census Bureau, 2018: Phoenix, AZ, mean statistical area populace. Accessed 4 October 2018, https://www.census.gov/ library/publications.2015.html.

U.S. EPA, 2003: Guidelines for developing an air quality (ozone and $\mathrm{PM}_{2.5}$ ) forecasting program. U.S. Environmental Protection Agency Rep. EPA-456/R-03-002, 126 pp.

__ 2018a: Updates to the Air Quality Index (AQI) for ozone and ozone monitoring requirements. U.S. Environmental Protection Agency Ozone Rep., accessed 7 October 2018, 6 pp., https://www.epa.gov/sites/production/files/2015-10/ documents/20151001_air_quality_index_updates.pdf.

_ 2018b: Air data: Air quality data collected at outdoor monitors across the US. U.S. EPA, accessed 1 August 2018, https:// www.epa.gov/outdoor-air-quality-data.

VanCuren, R., 2015: Transport aloft drives peak ozone in the Mojave Desert. Atmos. Environ., 109, 331-341, https://doi.org/ 10.1016/j.atmosenv.2014.09.057.

Wang S.-Y., R. R. Gillies, E. S. Takle, and W. J. Gutowski Jr., 2009: Evaluation of precipitation in the Intermountain Region as simulated by the NARCCAP regional climate models. Geophys. Res. Lett., 36, L11704, https://doi.org/10.1029/ 2009GL037930.

Wayne, R. P., 1987: The photochemistry of ozone. Atmos. Environ., 21, 1683-1694, https://doi.org/10.1016/0004-6981(87)90107-7. 